To face $\mathrm{p} 461$.

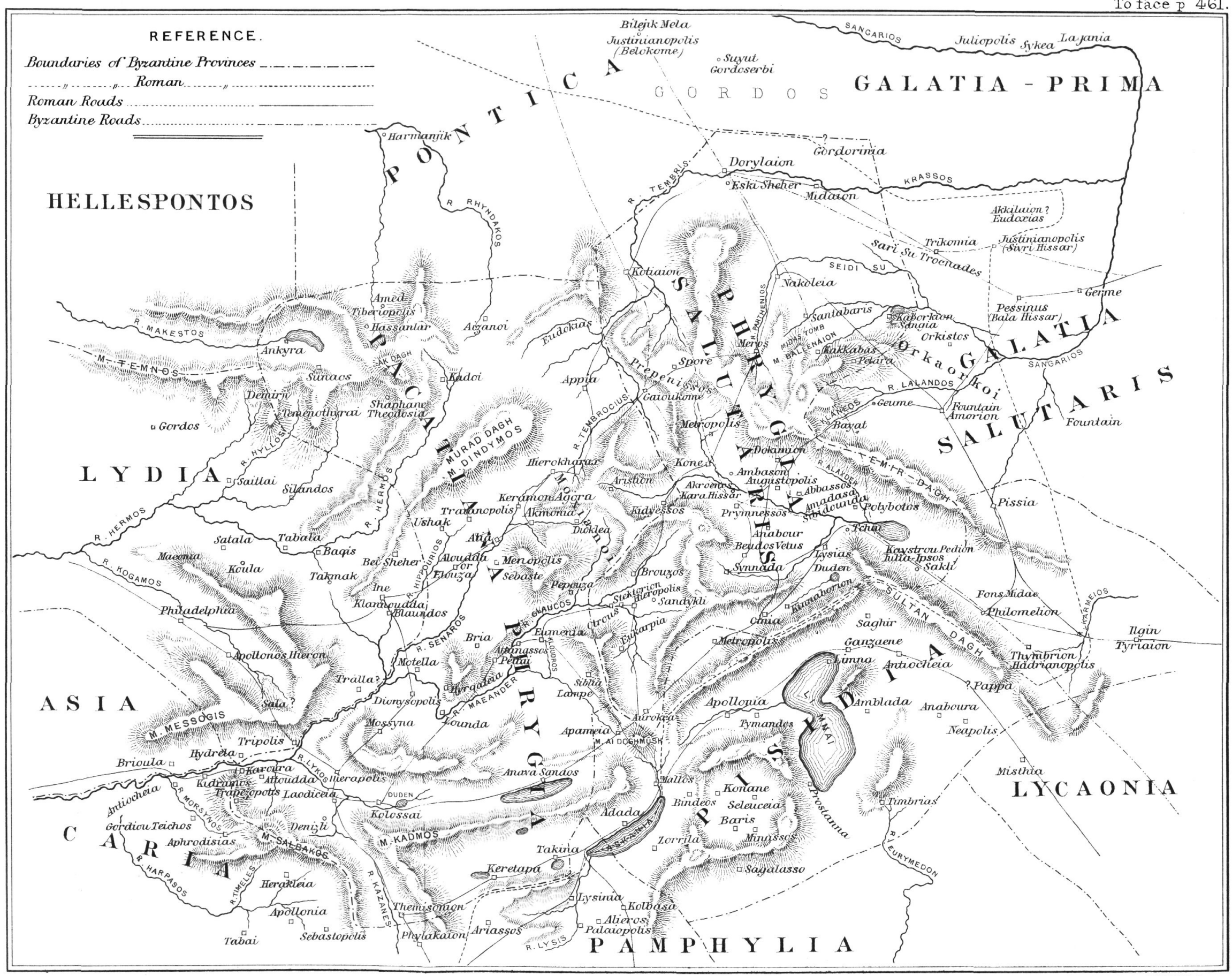

CF. KELL, LITHO, B, FURNIVALSTHOLEORN, E. 


\section{THE CITIES AND BISHOPRICS OF PHRYGIA.}

\section{Part II.}

THE study of the Phrygian cities, the concluding part of which is here published, claims to be complete in the sense that it enumerates and places every polis, i.e. district, which had at any period a self-centred municipal existence; besides this it enumerates and discusses many villages and towns which formed part of the territory of these $\pi o^{\prime} \lambda \epsilon \iota$. The hope of the writer is to make a study of the local history of the whole central plateau of Asia Minor, tracing from the beginning of recorded history to the Mohammedan conquest the varying fortunes of every district, collecting the scanty indications of its social condition at different points in this long time, and essaying a picture of the growth and decay (which sometimes recur in a second cycle) of its civilization. The present study is restricted by the conditions of available space to the narrowest limits of a preliminary survey of the entire country of Phrygia. This survey is founded on certain principles, some of which are here enunciated for the first time, while others have been to a certain degree recognized and stated by M. Waddington and Professor Hirschfeld, though they have never been consistently applied and carried out to their logical conclusion. I may here briefly state them.

1. The Byzantine ecclesiastical lists (including Hierocles' Synekdemos) must be the foundation of any systematic investigation of Anatolian antiquities.

H.S.-VOI. VIII.

H Ii 
2. These lists are complete for their respective periods, and the discrepancies between them are all to be explained by the modifications of provincial organization and ecclesiastical rank.

3. The order of enumeration adopted by Hierocles, when once his principle is understood, may be pressed very close as topographical evidence. ${ }^{1}$

4. The ecclesiastical subdivisions of the various provinces were made strictly according to locality: each subdivision is a distinct local group of bishoprics. This principle, towards which I was gradually forced in writing Part I., and which I there advanced with much hesitation, has proved itself in the following cases: (1) the Hierapolis group, (2) a second Hierapolis group, (3) the Khonai group, (4) the Akmonia group, (5) the Kotiaion group, (6) the Amorion group, (7) the group along the Roman road Kormasa-Kretopolis in Pamphylia. ${ }^{2}$

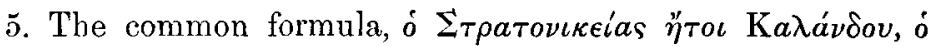
$\Pi a \lambda a \iota$ ก correctly interpreted by Professor G. Hirschfeld as giving the names of two neighbouring towns, and not two names for the same town. The reason lies in an historical process of great interest-the gradual transition from the Graeco-Roman sites, easy of access and either defenceless or strong through artificial fortifications, to a different kind of situation, which suited the disturbed state of the country when Sassanian, Arab, and Turkish conquerors successively swept over Asia Minor.

6. A modern town or village of more importance than its neighbours 11sually corresponds to each ancient city, though it is generally on a different site. The reasons which lead to change of site form the subject of a special investigation $;^{3}$ but the

1 I except Lydia and Hellespontus, of which the lists are very puzzling, both in order and in extent; they seem to me not to be founded on ecelesiastical lists, and to be unique in their character among all the provinces of Asia Minor.

2 (3) and (7) are discussed in my 'Antiquities of Southern Phrygia and the Border Lands,' sec Amer. Journ.
Arch. 1887 and 1888 : the others are discussed in the course of the present paper.

${ }^{3}$ This investigation forms the subject of a paper which will, I hope, soon appea: in the Transactions of the Royal Geographical Society ; the reasons in brief are (1) change in the lines of road, (2) military strength, (3) water supply. 
fact of such correspondence often furnishes topographical evidence.

7. In the Peutinger Table the distances, apart from frequent inaccuracy, are reckoned from city to city; the cities often lay a little apart from the direct line of road, and the sum of separate distances is therefore decidedly greater than the whole length of the roal. The distances on milestones, in the few cases where we know them, are reckoned direct along the road. ${ }^{1}$

8. The lists of bishoprics in each province given in the Notitice do not exactly correspond with the actual facts of any single period, and are often self-contradictory. Thus in Notitiae VIII., IX., Amastris occurs twice, both as an archbishopric and as a bishopric subject to Gangra; it was created an archbishopric about 800 , and obviously in these Notitice the list of the province of Paphlagonia has been left uncorrected. In the later Notitie, I. Amastris is entered only as an archbishopric: the list of Paphlagonia has been corrected. Such a fact, which is typical of a large class, shows how carelessly the modification and rectification of the registers was performed.

9. Allowing for this character of the Notiticu, they may be arranged in the following chronological order : VII. is the oldest, and while it contains some facts of the ninth century, it in general represents the state of the Eastern Church at a decidedly earlier time; it is much to be regretted that so large a part of it is lost, including the whole of Phrygia Pacatiana. VIII. and IX. are almost identical, and stand between VII. and I. I. is dated A.D. 883, but is not corrected up to date: in one case (see C) it gives an arrangement which had been disused before 787. III., X., XIII. are the latest, and in some respects show the changes effected by the Palaeologi, but alongside of this show some marks of a much earlier time. The other published Notitiae give only the metropoleis and archbishoprics, and not the lists of bishoprics subject to the various metropoleis.

10. The lists of metropoleis at the beginning of most Notitice are much more carefully corrected to date than the lists of

1 I have proved this in detail in in my "Antiquities of Southern regard to the great eastern highway Plirygia.' 
subordinate bishoprics, the latter sometimes giving a state of things centuries earlier than the former.

11. The terms, city ( $\left.\pi \hat{o}^{\prime} \iota \varsigma\right)$ and bishopric, are coextensive, and Hierocles' list of poleis is therefore equivalent to the list of bishoprics of his time, and has been very greatly influenced by ecclesiastical lists.

12. The order of precedence among the metropolitans cannot be proved to have been settled earlier than Justinian; certain lists of bishows at Concil. Chalced. A.D. 451, which are arranged in the later order of precedence, are made at a later time. The order of precedence was probably settled by Justinian, though I have not as yet found any certain prouf of this.

XX.-A passage of Strabo ${ }^{1}$ proves that there was in Phrygia a city bearing the name of the god Men. Men Askaenos was worshipped in the two cities immediately adjoining Sebaste, viz. Alia and Eumeneia. This suggests the probability that the Menopolis of Strabo, which must be a place of some consequence and which yet has left no other memorial of itself, changed its name to Sebaste under Tiberius, who is known to have nade some changes in Phrygia and Pisidia. ${ }^{2}$

XXI.-ELoUza or A toUdDA struck no coins : considering its advantageous position on a great road, this can hardly be explained except by its being subject to Sebaste: this would also explain why Dios Kome (at Kabaklar) was subject to Sebaste, as is shown to have been the case by the inscription which mentions it.

XXII.-Akmosia was situated at Ahat Keui, as has almost universally been agreed by writers of this century. Situated on a half-isolated hill between two confluent streams, it must have been a fortress of the first importance in ancient time. It was a caput viae, roads radiating from it to Apia and Kotiaion, to

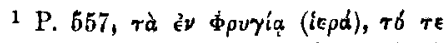

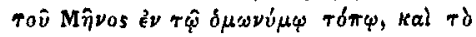

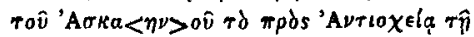

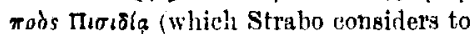

be in Phrygia), \&e.

2 Tiberiopoiis in Phrygia, Pappa Tiberia in Pisidia, derive their name or second name from him. 
PHRYGIA PACATIANA.

[To face XXII.

\begin{tabular}{|c|c|c|c|c|c|}
\hline Ptolemy. & Corns. & $\begin{array}{l}\text { CounCiL OF CHALCEDon, } \\
451 .\end{array}$ & HiERoCLES, 530 & Notrite I., VIII., IX. & Notitia III., X., XIII. \\
\hline$[\Lambda \alpha, \delta$ Ifreta] & $\triangle A O \triangle I K E \Omega N$ & Laodiceia & $\Lambda \alpha o \delta i \kappa \in \iota \alpha$ & 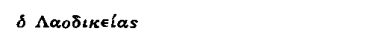 & $\delta \Lambda \alpha o \delta_{z} r \in i a s$ \\
\hline 'IEpámoגıs & IEPAIIOAEIT $\Omega N$ & (Hierapolis, Conc. Ephes.) & 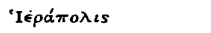 & II. $\delta{ }^{\star} I \epsilon \rho \alpha \pi \delta \lambda \epsilon \omega s$ & 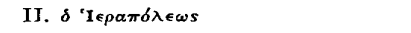 \\
\hline Inser. 120 A.D. & $\ldots \ldots$ & Mossynoi & 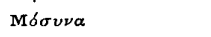 & II. $6, \mathbf{M o \sigma u ́} \nu \omega \nu, M \in \sigma u ́ \nu \omega \nu$ & 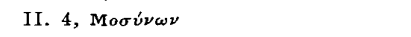 \\
\hline 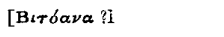 & ATTOT $\triangle E \Omega N$ & Attoudda & ${ }^{*} \mathrm{~A} \tau \tau \nu \delta a$ & II. 5, 'A $\mathrm{A} \tau \tau o \nu \delta \omega \nu,{ }^{\prime} \mathrm{A} \tau \gamma o v ́ \delta \omega \nu$ & 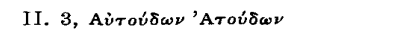 \\
\hline$[\mathrm{T} \rho \alpha \pi \in \zeta o v \dot{\pi} \sigma \lambda \iota s]$ & TPAПEZOחOAEITSN & Trapezopolis & 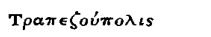 & 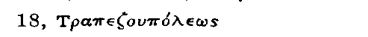 & $2, \mathrm{~T} \rho \alpha \pi \epsilon \zeta o v \pi \delta \lambda \epsilon \omega S$ \\
\hline (Herod; Strabo) & KOAOEZHNRN & Colossae & $\mathrm{K} o \lambda \alpha \sigma \sigma \alpha \dot{I}$ & [District separate] & III. $\delta \mathrm{X} \omega \nu \hat{\omega} \nu$ \\
\hline$\triangle\llcorner а к \alpha \iota \sigma a ́ \rho \in \iota \alpha$ & 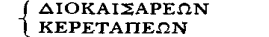 & Ceretapa & 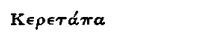 & [District separate] & $5, \mathrm{X} a\left\llcorner\rho o \tau \delta \pi \omega \nu, \mathrm{X} \alpha \iota \rho \in \tau \alpha^{\prime} \pi \omega \nu\right.$ \\
\hline$\Theta \epsilon \mu t \sigma \omega ́ \nu t o \nu$ & 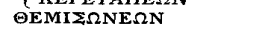 & Themissos & $\Theta \epsilon \mu \tau \sigma b \nu t o s$ & [District separate] & $19, \Theta a \mu \psi\llcorner o v \pi \delta ́ \lambda \in \omega s$ \\
\hline$[\mathbf{r} a ́ \gamma \eta \nu \alpha ?]$ & $\ldots \ldots$ & ...... & 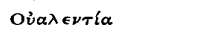 & [District separate] & $\ldots \ldots$ \\
\hline savts & $\ldots \ldots$ & Nea (i.e. Sanea ?) & হavaós & [District separate] & $18, \Sigma_{\nu \nu \alpha o \bar{v}, \Sigma_{\iota \nu \alpha o \hat{v}}}$ \\
\hline$\left(\begin{array}{l}\text { Pliny }) \\
\text { (Pliny })\end{array}\right.$ & 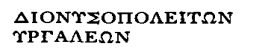 & $\begin{array}{l}\text { Dionysopolis } \\
\text { (Anastasiopolis, Conc. 536) }\end{array}$ & 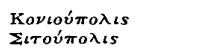 & 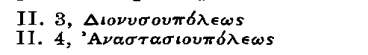 & \}II. $5, \Phi d \beta \omega \nu$ \\
\hline [Village of & Eumeneia] & Atanassos & $\mathrm{K} \rho \dot{\alpha \sigma o s, \mathrm{~K} \rho \alpha \sigma \sigma o s}$ & $17,{ }^{\prime} \mathrm{A} \tau \tau \alpha \nu \alpha \sigma \sigma o \hat{v}$, 'A $\mathrm{A} \gamma \alpha \nu \alpha \sigma o \hat{v}$ & 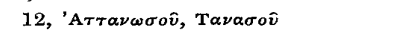 \\
\hline Inser. $200 \mathrm{A.D}$. & OKOKAIE $\Omega N$ ? & (Lounda, Syn. vii.) & $\Lambda \circ \bar{\nu} \nu \delta a$ & [District separate] & $13, \Lambda \circ u ́ \nu \delta \omega \nu$ \\
\hline 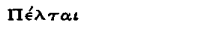 & 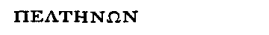 & Peltae & $\mathbf{M} \delta \dot{\lambda \tau \eta}$ & $5, \Pi \epsilon ́ \lambda r \omega \nu$ & 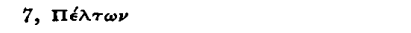 \\
\hline Eủnéveta & ETMENE $\Omega N$ & ...... & Ė̉uéveta & 12, Ẻ̉uevefas & 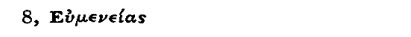 \\
\hline$\Sigma i \lambda \beta_{\iota o \nu}$ & ¿EIBAIAN $\Omega N$ & Silbium & $\Sigma i \beta \lambda i \alpha$ & $19, \Sigma_{\iota}<\lambda i \omega s, \Sigma_{\iota \kappa} \lambda l o s, \Sigma_{\iota \kappa} \lambda i o v$ & 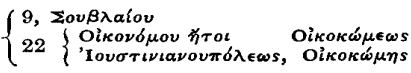 \\
\hline$\cdots \cdots$ & ...... & $\cdots \cdots$ & 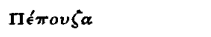 & $. \quad \ldots .$. & $\ldots \ldots$ \\
\hline$\ldots \ldots$ & BPIAN $\Omega N$ & ...... & B $\rho i a \nu \alpha$ & 18, 'I $\kappa_{\kappa} \rho l_{\omega \nu}$ (i.e. 'I $\left.\boldsymbol{\beta} \rho \rho^{\prime} \omega \nu\right)$ & $\ldots \ldots$ \\
\hline (Menopolis Strab. ?) & \EBAZTHN $\Omega N$ & Sebaste & $\Sigma \in \beta a \sigma \tau \dot{n}$ & $11, \sum_{\in} \beta \alpha \sigma \tau \hat{\eta} s, \Sigma_{\in} \in \beta \alpha^{\prime} \sigma \eta s$ & $4, \Sigma \in \beta a \sigma \tau \in$ tas \\
\hline$\left[{ }^{\gamma} \mathrm{A} \lambda v \delta \delta \alpha\right]$ & $\ldots \ldots$ & Ilouza & ${ }^{\gamma_{I} \lambda o v \zeta \alpha}$ & 9, Kapias, I入oú $\zeta \omega \nu$ & 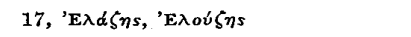 \\
\hline 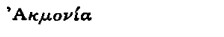 & 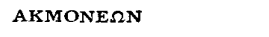 & Akmonia & 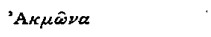 & [District separate] & 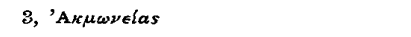 \\
\hline$\cdots \cdots$ & AAIHN $\Omega N$ & Alianoi & 'A $\delta\llcorner o$ ใ & 15, 'A $A\{\nu \omega \nu$ & $16, ' \Omega p\{\nu \omega \nu ?$ \\
\hline$\left\{\begin{array}{l}\text { Mokeavol } \\
\Delta u \delta \kappa \lambda \in i a, \text { or } \\
\Delta \delta \kappa \in \lambda a\end{array}\right.$ & 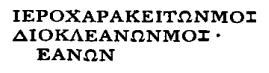 & Diokleia $\quad \cdots \cdots$ & 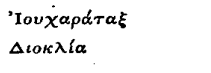 & $\begin{array}{l}\text { [District separate] } \\
\text { [District separate] }\end{array}$ & 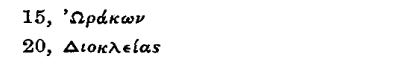 \\
\hline$\kappa \nu \delta \iota \sigma \sigma \epsilon \hat{\imath} s$ & $\cdots \cdots$ & Aristion & 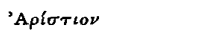 & [District separate] & 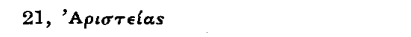 \\
\hline Rototovets & $\mathrm{KI} \Delta \mathrm{TH} \Sigma \Sigma \mathrm{E} \Omega \mathrm{N}$ & Kydissa & $\mathbf{K} \iota \delta v \sigma \sigma \delta s$ & [District separate] & $14, \mathrm{~K} \iota \delta \iota \sigma \sigma o \bar{v}, \mathrm{~K} \eta \delta \iota \sigma \sigma o \bar{v}$ \\
\hline$K \in \rho \kappa \omega \pi i \alpha$ & ATIIIAN $\Omega N$ & Philippopolis? & 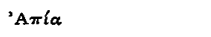 & $6, ' A \pi \pi i \alpha s, \sum \in \pi i a s$ & 6, 'Amelas \\
\hline$\cdots \cdots$ & $\cdots \cdot \cdot$ & ....... & Eủsokias & $\ldots \ldots$ & 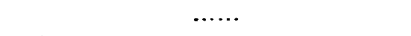 \\
\hline A Savoí & AIZANEIT $\Omega N$ & ...... & 'A Savoi & $3, ' A \zeta \alpha \nu \bar{\omega} \nu, ' A \zeta \alpha u ́ \nu \omega \nu$ & II. $10, \mathrm{Z} \alpha \nu \bar{\omega} \nu$ \\
\hline 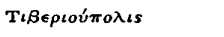 & TIBEPIOПONEIT $\Omega N$ & ...... & 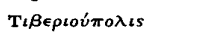 & $2, \mathbf{T} \iota \beta \in p \iota o v \pi \delta \lambda \in \omega s$ & II. $8, T \iota \beta \in \rho\llcorner o v \pi \delta \lambda \epsilon \omega S$ \\
\hline$[\mathrm{K} \alpha \dot{\delta} \delta \iota]$ & KA $\triangle O H N \Omega N$ & Kadi & Ká $\delta o \iota$ & $7,{ }^{\prime} \mathrm{A} \kappa \delta \delta \omega \nu, \mathbf{K} \alpha \dot{\delta} \omega \nu$ & II. $9, K \alpha \nu \hat{\omega} \nu$ \\
\hline$\ldots \ldots$ & $\ldots \ldots$ & Theodosiopolis & 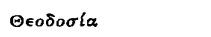 & 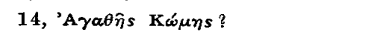 & 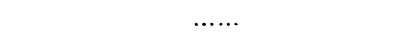 \\
\hline${ }^{\top} \mathrm{A} \gamma \kappa \nu \rho \alpha$ & ATKTPANתN & $\ldots \ldots$ & 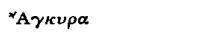 & 'Aykúpas & II. 6, 'Aүrкúpas \\
\hline Súvaos & 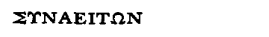 & Synnaos & 乏úvขaos & 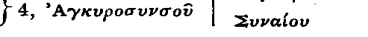 & 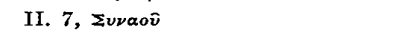 \\
\hline (Pausanias) & 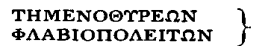 & Temenothyrae & 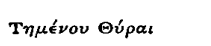 & 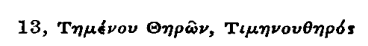 & 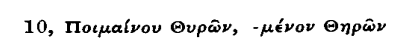 \\
\hline$\left\{\begin{array}{l}\text { Grimenothyritai } \\
\text { Tpaıavónoגis }\end{array}\right.$ & $\left.\begin{array}{l}\text { ГPIMENOÐTPE } \Omega N \\
\text { TPAIANOMOAEIT } \Omega N\end{array}\right\}$ & $\cdots \cdots$ & Tavoú $\pi a \lambda ı s$ & $10, \mathbf{T} \rho a \nu o \nu \pi b \lambda \in \omega s$ & 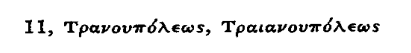 \\
\hline Inser. c. 138 A.D. & $\ldots \ldots$ & $\ldots \ldots$ & 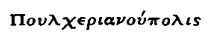 & 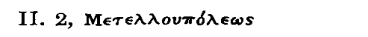 & 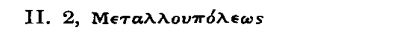 \\
\hline
\end{tabular}


Philadelphia and Smyrna, and to the Pentapolis (see XXXIV.). I found the eleventh milestone from Akmonia on the Hamam Su (Ephem. Epigr. 177 and 1399) ${ }^{1}$ a few miles north of Islam Keui.

The inscription published in Part. I. 30, was not completely restored : I have since published a study of it, ${ }^{2}$ and add here the

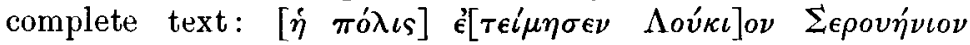

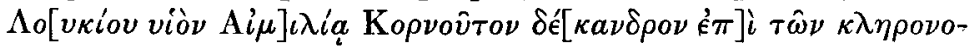

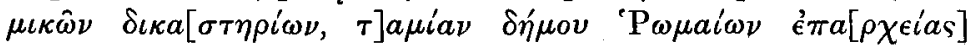

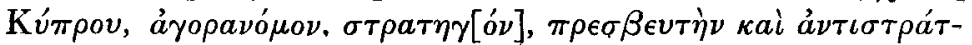

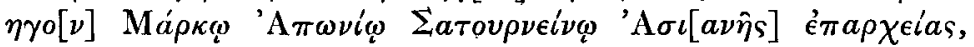

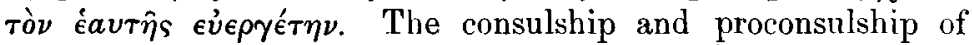
Aponius Saturninus, who is familiar to us from Tacitus' Histories, were hitherto unknown.

XXII. bis.-Keramon Agora. When Peltai has been fixed near the Maeander, and Caystri Pedion and the Fountain of Midas have long been determined by Hamilton, there can remain no doubt that Keramon Agora was somewhere near Akmonia. The modern village of Islam Keui occupies a site of the very first importance: it lies where the narrow valley of the Hamam $\mathrm{Su}$ opens on the great plain named the Banaz Ova, amid an open, fertile, and well-watered country. All communication between the cities of the Banaz Ova and the country to the north, north-east, and east must pass through Islam Keui and up the Hamam Su.

The Royal road of Herodotus, from Sardis to Susa, followed this route: so also cid the Roman road from Smyrna, Sardis, and Philadelphia to Kotiaion, Dorylaion, and the north-east. It is a necessity of nature that the Anabasis of Cyrus should follow this road, and military considerations make it a practical certainty that an army, if it balted anywhere between Peltae and Caystri Pedion, would halt near Islam Keui. I have therefore great confidence in placing Keramon Agora here.

In the Roman period it is clear that Keramon Agora, though certainly an important place, to judge from the remains, was not an autonomous city, but subject to Akmonia.

At some unknown period Akmonia must have been raised to

1 I refer by the numbers to the two Supplements to C.I.L. vol. iii. pub- lished in the Ephemeris Epigraphica. 2 Amer. Journ. Arch., 1885. 
the dignity of a metropolis, and a group of bishoprics (XXIV.XXVII.), lying along the roads which lead from the Banaz Ora to the north-east and east, was subjected to its authority. This arrangement is evidently unknown to Hierocles, and is therefore later than his time, and the Council lists of A.D. 536,692 , and 787, show that it did not exist in those years. But Notitiae I., VIIL., IX. omit the five bishoprics, which form a frontier district, and this omission can be explained only by the separation (perhaps merely temporary) of this district from the control of the metrupolis Laodiceia.

XXIII.-ALIA must probably be placed near Kirka, as I have already stated. The order of Hierocles shows that it must be near Akmonia, and the fact that it is not included in the district subjected in later time to Akmonia suggests a situation on the west.

Two references to this obscure city may be mentioned here.

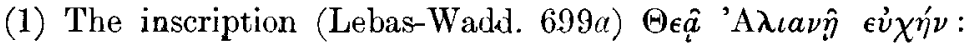
M. Waddington remarks that la déesse Aliune est inconnue, but if we understand her as the goddess of Alia, her character and seat of worship are determined: such titles, $\Theta \epsilon a \grave{a} \Lambda a \gamma \beta \eta \nu \eta^{\prime}$,

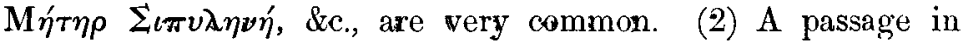
Aelian, ${ }^{1}$ when compared with the discussion of Sabazios, Sozon, and Men, which I have given elsewhere, ${ }^{2}$ and with the account which Clemens Alex. gives of the Phrygian Mysteries, shows what was the character of the god Men Askaenos, who appears on coins of Alia and on a votive relief found near the site of the city.

XXIV.-Hieror harax appears in Hierocles under the corrupt form Iouk haratax, which I corrected conjecturally to Atyokharax. The only evidence of the correct form is a coin of Geta, belonging to M. Waddington, with the legend

\section{IEPOXAPAKEIT $\Omega N$ MOI $\epsilon a \nu \hat{\omega} \nu$.}

The I must be understood as an incomplete 1 , and Hiero-

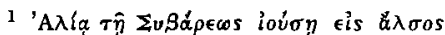

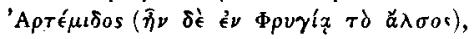

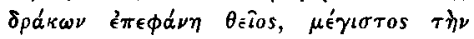
$\iota \psi\left(\nu\right.$, ral $\dot{\omega} \mu i \lambda \eta \sigma \epsilon \nu$ àj $\hat{\eta}$. Aelian, $D_{e}$
Anim. XII. 39.

2 'Antiquities of Southern Phrygia and the Border Lands,' in Amer. Jou'n. Arch. 
kharax was evidently one of the two cities in the territory of the Moxeanoi, which vied with each other for the honour of first city of the tribe (see XXV.)

XXV.-Dokela or Diokled vied with Hierokharax (see XXIV.), and apparently the rivalry between the two was submitted to the Roman authorities and decided in favour of

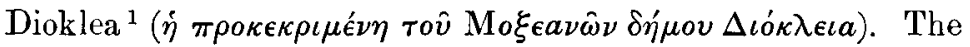

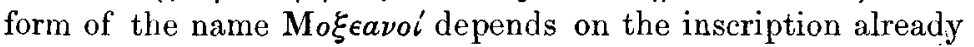
printed, which I again verified in July 1887. Coins of Dioclea and Hierokharax give $I$ not 1 , but it must be read as an imperfectly formed $x i$.

Dioclea is situated on the road from the Banaz Ova to the Sandykli Ova (see XXXIV.); Hierokharax on the road from the Banaz Ova towards Apia and the north, and towards Paroreios Phrygia and the east generally.

XXVI.-Aristion or Aristeia : this town is mentioned only in the Byzantine Lists. Hierocles gives it between Dioklea and Kidyessos: it must therefore be placed in the western half of the Sitchanli Ova, where some inseriptions, marbles, and large blocks of squared stone, in the villages of Ginik, Göne, Karadja Euren, and Duz Agatch, indicate an ancient site. The evidence lies only in the situation of Kidyessos and the order of Hierocles and of the Notitiae (Dioklea and Aristion always together). The country does not seem very rich, and no coins of Aristion are known.

XXVII.-KIDYEssos is proved to have been in the eastern part of the Sitchanli Ova by an inscription, almost defaced, on a block of marble in the cemetery at Bulja, which I copied in June 1883. It is very badly defaced, but after some study I could read the name CPATIANON of the emperor honoured in the inscription and most of the letters (fragments of each alone remaining) of $\dot{\eta} \mathrm{K} \iota \delta v \eta \sigma \sigma \sigma^{\prime} \omega \nu$ ró $\lambda \iota s$. This inscription completely upset all my previous topographical views about this district, but has since then proved itself true by working in so well with all subsequent discovery. ${ }^{2}$

1 Compare the history of the rivalry between Ephesos and Smyrna, Tarsos and Anazarbos, Nicaea and Nicomedia, \&e.
2 Without such confirmation the existence of a decree of Kidyessos here would not be sufficient proof that the neighbouring city was Kidyessos. 
Kidyessos commands a very fertile territory, and was a station on the Roman road between Conni and Brouzos. Its coins, from Nero to Otacilia, mention the magistracies, Logistes and

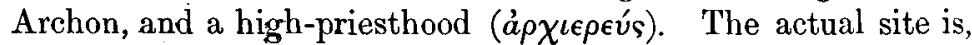
I think, at a village reported in 1883 by my companion, $\mathrm{Mr}$. Sterrett, as Cutch Eyuk, but whose real name must, I think, be Geukche Eyuk. ${ }^{1}$

XXVIII.-Pacatiana and Salutaris. Before proceeding further, it is necessary to discuss the Byzantine division of Phrygia into two provinces, which, roughly speaking, was consummated about A.D. 300 .

The boundaries will become clear in the discussion of the several cities, and are given in the annexed map. It is obvious that these boundaries are entirely inconsistent with the old Roman division into conventus, as the following lists of the various eonventus will show. In each $\mathbf{I}$ give first the cities actually mentioned by Pliny as belonging to it, and add the other places within the limits thus indicated which are known to have been self-administering eommunities during the first centuries after Christ.

1 Everyone who has tried knows the difficulty of catching the proper form of Turkish names from the badly articulated pronunciation of peasants. Geuk means blue, Genkche bluish, and Eyuk tumulus: both are very eommon in Turkish nomenclature.

2 I disregard here the well-known controversy as to the time and manner of this division, which is for our pre. sent purpose immaterial. 

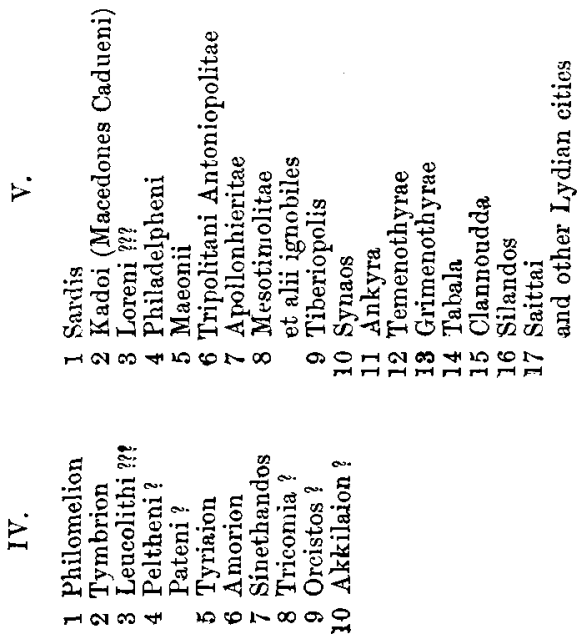

年

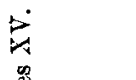

E

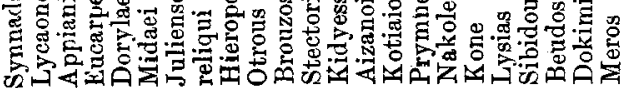
$\operatorname{man} 2 \sin$ $\infty$ o 0 페 की
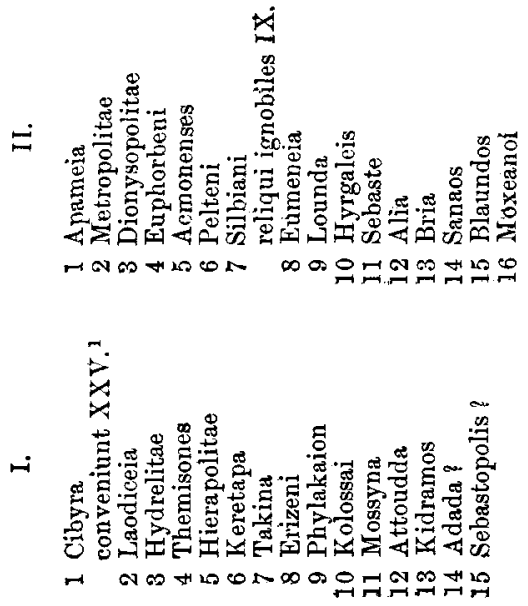

$\ddot{\circ}$ 
Now it is naturally probable, and it is confirmed by various facts which would find their place in a full discussion of the provinces, that the lines of demarcation in the new Byzantine organization followed existing divisions to a very considerable extent, and that the reorganization attributed to Diocletian confirmed a tendency which had already been in operation. Hence, since the new organization utterly disregards the old conventus, I infer that the conventus had either been greatly subdivided ${ }^{1}$ or had ceased to exist before the time of Diocletian. The Pentapolis (see XXIX.) was perhaps one of a number of administrative districts, which replaced the old conventus.

When the two new provinces of Phrygia were formed there were at first no generally recognized names to distinguish them. The Verona MS. calls them Phrygia Prima and Secunda, Polemius Silvius (ab. 385) calls them Phrygia (Prima? omitted) and Phrygia Secunda or Salutaris (the MSS. vary). ${ }^{2}$ Carophrygia also occurs as the name of the eastern province about the middle of the four th century: in Theodoret, Hist. Eccles. iv. 8.

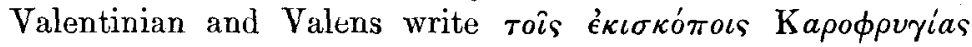

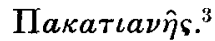

The names Pacatiana ${ }^{4}$ and Salutaris ${ }^{5}$ Phrygia came into use already in the fourth century, and soon established themselves universally. Allowing for a certain interval after their first introduction before they were universally adopted, we may say that no example occurs later than about 400 in which the provinces are called by any other name, whereas all the rare references to them between 300 and 390 use some other name either alone or concurrently with the later name.

The name Parva Phrygia occurs in one or two rare cases in the sense of Salutaris. This points to a distinction made at

1 Marquardt (1. 341) has shown that Philadelphia became the seat of a contentus between the times of Pliny and of Aristides.

2 The variation indicates that the later and common name was substituted in one MS. for the disused title Secunda.

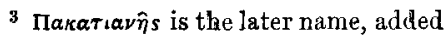
perhaps by Theod. himself, or by a seribe, to explain the name actually used by the emperors.

4 The name Iacatiana occurs as a highly probable correction, Cod. Theodos. xi. 23,3 (rejected however by Gothofredus), A.D. 396, and in Not. Dignit., A.D. 413.

5 Salutaris first occurs in the case quoted above from Polem. Silv., where it is probably due to later correction, 
one time between the two provinces as Great and Little. The preceding paragraph has shown how natural these names were in the early period when the provinces were called First and Second, and how easy it is to understand the conflict between many different names for the new provinces, and the final triumph of one particular pair, which are henceforward used by all writers for the following 500 years. On the other hand it is inherently improbable that after the provinces had existed for more than two centuries, and after two names had established themselves in universal use for nearly 150 years, the names Magna and Parva should come into use, survive in one or two instances, and again disappear, leaving the old names Pacatiana and Salutaris once more victorious. This view has no presumption in its favour, and cannot of itself, without some other corroborative evidence, be allowed. The conclusion therefore is that if the term Parva is used in the sense of Salutaris in a Byzantine document of doubtful date, the document was probably written during the fourth century.

This argument, which I advanced in brief terms in this Journal, 1882, p. 345, is rejected by M. Duchesne, ${ }^{1}$ who thinks that when Justinian, A.D. 536, raised the governor of Pacatiana to the rank of comes spectabilis, the province acquired the title magna in contrast with the lower rank of the governor of Salutaris. But it was of course on account of the well-known superiority in size, wealth, and importance of Pacatiana that Justinian so honoured it; he did not make it the great province but promoted it on account of its already existing and recognized greatness. Again, if the names Magna and Parva were introduced under Justinian, how does it come that not a single example of their use can be proved afterwards? On my theory the disappearance of the names is simple and natural, on M. Duchesne's theory it is unintelligible. When I stated my theory at first it seemed so obviously true that I thought it unnecessary to search for proofs; but, when challenged for proof, I appeal to the following passages.

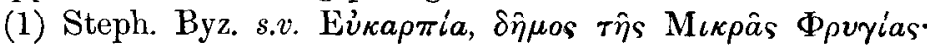

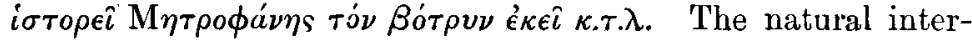
pretation of this passage is that Metrophanes is the authority throughout, and that he nsed the term $\Phi$ puria Mıкрá; he is

1 'Saint Abercius,' in Revus des Qucst. Histor., 1883, p. 21. 


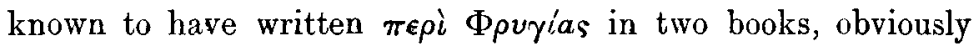
devoting one book to each province.

What then is the date of Metrophanes? In Smilh's Dictionary no date is given to him, but the references in Waitz, Rhetores Graeci (see index s.v.), show that he was later than Minucianus (about 270) and earlier than Syrianus (about 430). Space forbids ne to enter here on the point; but I may say that my investigation was made and the date fixed with the help of Mr. Bywater.

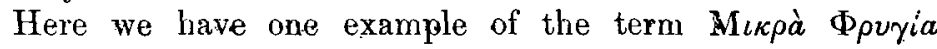
denoting Phrygia Salutaris during the fuurth century.

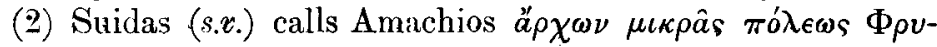
yias, and tells the story of his execution of four Christian martyrs under Julian (A.D. 364). Socrates (iii. 15) and Sozomen (v. 11) tell the same story, mentioning that Amachius was governor of the province; and therefore we must either read in Suidas, as has been proposed by Wesseling with general appruval, á $\rho \chi \omega \nu \mathrm{M}_{i \kappa \rho a ̂ s} \Phi \rho v \gamma i a s$, or suppose that

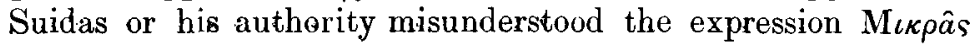
Sovyias in the original account of the incident and inserted $\pi o ́ \lambda \epsilon \omega s$. In either ease we are forced back to an original authority using the expression Little Phrygia. The error is unintelligible if Salutaris Phrygia was the name in the earliest accounts. This earliest authority must be older than Socrates

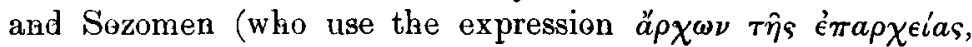
$\dot{\eta} \gamma \epsilon \mu \dot{\omega} \nu$, or á $\rho \chi \omega \nu$ simply), and must therefore be very little later than the actual occurrence. The improbability of M. Duchesne's hypothesis is elearly brought out by this example: according to his view the expression ă $\rho \omega \nu$ tîs

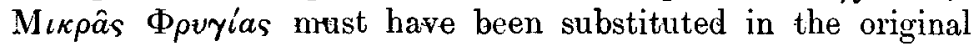
account by a writer soon after 535, for the name Mıkpà did not permanently establish itself, and can have suggested itself only to one writing under Justinian, and this writer of the sixth century must have been used by Suidas or by his authority.

Besides the ease with which my theory explains both the appearance and the disappearance of the name Little Phrygia, I have therefore made it probable that twe writers of the fourth century used the name. I now come to the original point in dispute - the date at which the legend of Saint Aberkios was composed. I first argued that it was composed 
shortly before A.D. 400. M. Duchesne prefers the sixth century or later.

My argument rested on the use of the term Little Phrygia, which seemed to me, and still seems, conclusive. I shall, however, give further evidence which leads me to the same view.

To discuss this question with authority, one ought to have studied the lives of the various Saints of Asia Minor. This investigation, when some one is found to undertake it, will repay the toil. Of those which I have hastily read over, a certain number, distinguished by local knowledge and multitude of details, make on me the impression of having been composed not later than the fifth century. Among these I would include the tale of Aberkios, the tale of Trophimus, Sabbatius, and Dorymedon, the tale of Ariadne of Prymnessos (Sept. 17th), the tale of Therapon (May 27th), ${ }^{2}$ Hypatius (June 17th: this dates about 450), \&e. These were written by natives of Phrygia, familiar with the country and obviously ignorant of other countries, and they abound in details which throw lioght on the state of the country at the time. About the yeir +00 there took place a very decided literary movement in central Phrygia, marked by such names as Metrophanes of Eucarpia, and by a Christian literature, of which only a few miserable remains have come down to us. The state of manners and of government in the martyr-romances is older than Justinian, e.g. the Asian Dioecesis is administered by a vicarius, ${ }^{3}$ whereas Justinian in 535 abolished the vicarius. One point in these romances is of special interest: when they were composed, the pagan religion was not eradicated, and they preserve to us some curious information : e.g. a feast of Artemis

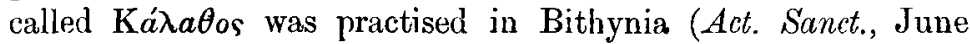
17th, p. 343).

1 In giving the limits 363 and 385 A.p. (though I used the datos only approximately) I made niy view seem too hard and fast : the latest date at which the tile was first reduced to writing is the time when Salutaris lecame the universally used term, and we can hardly place this earlier than the beginning of the fifth century.

a Mere excerpts of the stories of
Ariadne and Therapon are given in the Actro Sanctorum: if any MS. can be found containing their complete biogral hy, it will be topographically tery valuable.

3 Acta SS. Troph., Scbb., \&c., where also the governor resident at Syntiada has not the rank of consularis, which he had acquired some time before Justinian. 
Further, the date when the term 'Little Phrygia' came into use can be still more narrowly defined. About 38.5-9.5 Theodosius disjoined a large district from Phrygia, and used it to form a new province, Galatia Secunda (see LXXIV.). Pbrygia Secunda, already less important and wealthy, now became also smaller, than Phrygia Prima.

I must arlvert to one other argument, used by M. Duchesne:

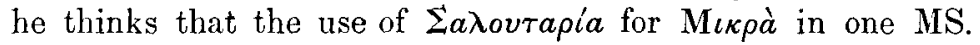
disproves my theory (suffit pour écarter le systeme proposé par le jeune savant anglais). But I cannot see why the substitution of the term which became practically universal soon after 400 , in all books known to us, for the term which was very rare, and which on my theory was disused about 400 , tells in any way against my theory: such a process is on my theory the most natural thing in the world of copyists.

One other objection to my theory, raised by myself in this Joumul, 1883, p. 425, remains. I there argued that the text of the epitaph was transcribed by the writer after the original inscription was defaced in one line, that this defacement was clearly intentional, and must have been done by some orthodox partisan who fancied that the line favoured heresy. I suggested the Paulician heresy as the one which led to this orthodox Vandalism; but Bishop Lightfoot in his work on Ignatius and Polycarp considers that heresies prevalent before 400 were quite sufficient to produce the same result, and it is moreover probable that the words were erased while the Saint was still remembered in the country, and while people still thought the stone an important religious monument. I still adhere to all that I said 1883 , p. 425 , except the suggestion about Paulicianism.

XXIX.-The Phrygian Pentapolis. This district may be noted as a typical example of the obscurity in which the topography of Phrygia was involved before the work of the Asia Minor Exploration Fund began. Of the five cities whose number caused the name, Eucarpia gave rise to frequent conjectures, none of which even approximated to the true situation. Of Brouzos M. Waddington ${ }^{1}$ remarks that it does not appear to be mentioned except in Hierocles. Of Otrous the same might be said. Hieropolis had been so entirely forgotten that it was confused with Hierapolis of the Lycus valley, and its bishops 


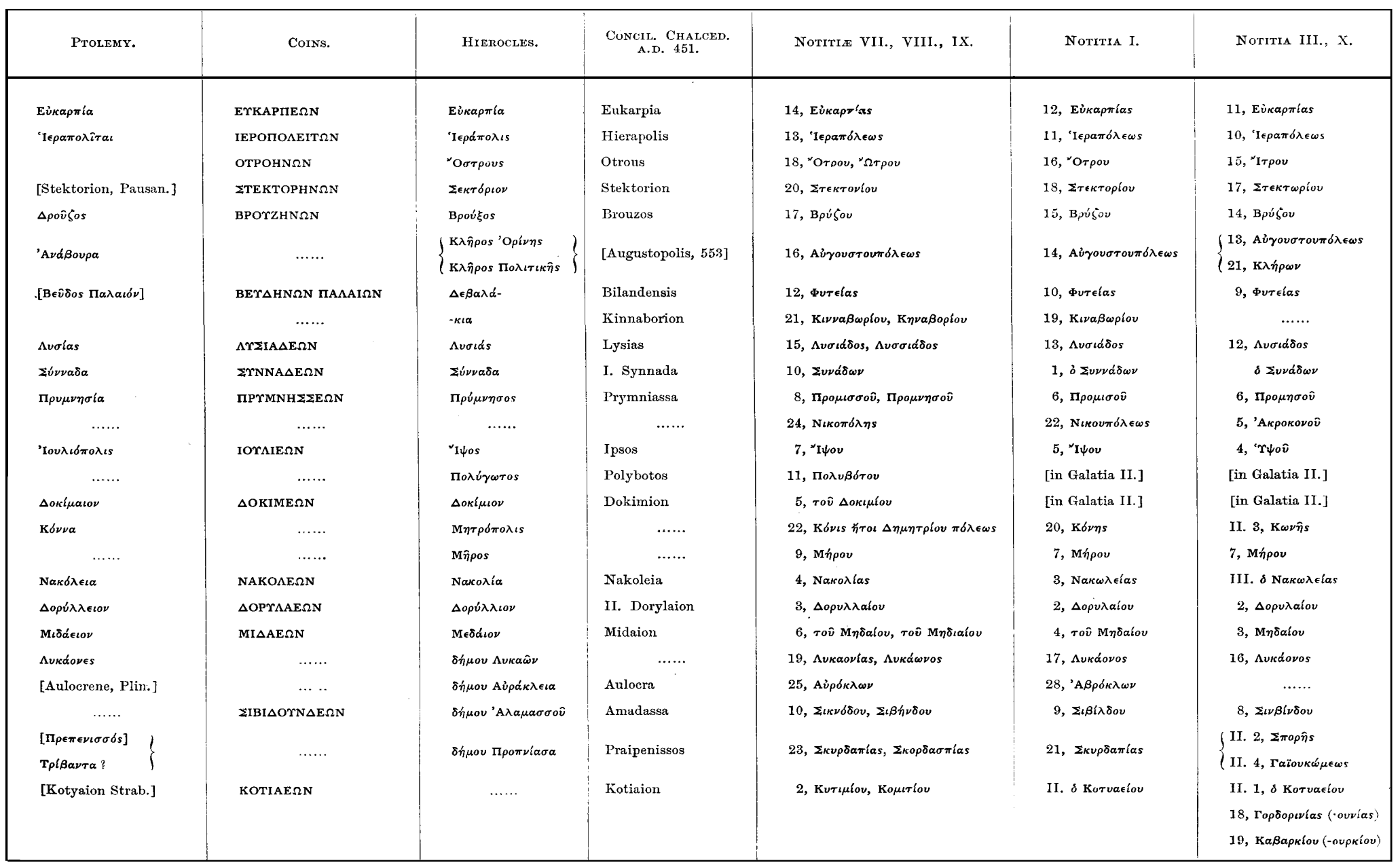


and its coins referred to the better known city ; ${ }^{1}$ Kiepert however observed the distinction and placed the second Hierapolis far away to the north, near Afiom Kara Hissar, which led him also to suggest situations for Stectorion and Otrous in the same neighbourhood. The name Pentapolis had not been observed, the five cities had not been. connected together, and no one of them had even by conjecture been placed in the valley of Sandykli where they were all situated. Hamilton proposed (and Kiepert accepts the hypothesis), to place Euphorbium in the valley of Sandykli (see LIII.).

The name Pentapolis is given in the following signature at Concil. Constantinop. A.D. 553 (Labbe, p. 585 [223]), ${ }^{2}$ Paulus misericordia Dei episcopus sanctae ecclesiae Stectorii civitatis Pentapoliticae regionis Phrygiae Salutaris provinciae.

In one other passage (Nicet. Chon., 162) the Phrygian Pentapolis is referred to. About the year 1158 there was a war between Manuel and the Seljuk Turks under Kilij Arslan, and

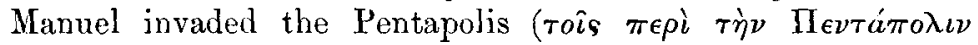
є $\pi \iota \tau(\theta \in \tau a \iota)$. Cinnamus describes this war more fully: he says that Manuel advanced by way of Philadelphia, but the rest of his vague description conveys no note of locality except $\chi \hat{\omega} \rho o^{\prime}$

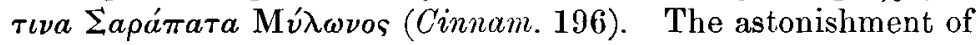
the Turks that a small Byzantine army should invade the district is vividly described by Cinnamus.

The order in Hierocles shows that the five cities are Eukarpia, Hieropolis, Otrous, Brouzos, and Stectorion. About these cities no trustworthy information existed until 1882, when I published in the Bulletin de Correspondance Hellenique a paper, 'Trois Villes Phrygiennes,' in which I showed that Brouzos was situated at Kara Sandykli, that Hieropolis must be a city of the same valley and probably Otrous also, and suggested that Eukarpia was to be sought in the country immediately north-east, and Stectorion south, of the Sandykli valley. In 1883 I visited the Sandykli Ova twice, first along with Mr. J. R. S. Sterrett in June, and again in October alone, in order to fill up some gaps in the

1 Forbiger, Alte Googr, does distinguish the two, but in the same page he makes three remarks about the lesser city which are true only of the greater.

$2 \mathrm{My}$ quotations from the Act. Coneil. ne marle from lists aml notes, somo written in Athens, some in Oxford (Mansi), some in Aberdeen : the paging varies according to three different editions. To reduce it to uniformity would necessitate wecks of toil, from which I shrink. 
evidence. I had previously spent two days in the valley in November 1881, and again in 1887 I spent four days; the last of these visits produced no new evidence.

The rich valley of Sandykli, in which the five cities were situated, lies on the upper waters of the Glaukos, a tributary of the Maeander. Sandykli is now the seat of a Kaimakam, in the Sanjak of Kara Hissar : it is a town of mediæval growth, placed, for convenience of water supply, on the higher eastern side of the valley, whereas the ancient cities all lay in the low rich land on the west side.

XXX.-EukarpIa. No direct evidence has yet been discovered about this city; but after placing the other four cities on wellmarked sites in the valley, there remains near Ille Mesjid one other ancient site, evidently the most important of all, as it possesses a small theatre, and the fifth city of the Pentapolis must be placed here. Corroborative evidence is obtained from the line of the Roman road. In the Peutinger Table Eukarpia is placed on the road from the north to Apumeia between Konna and Eumeneia. Geographical possibility leaves no doubt about the line of this road south of Konna: ${ }^{1}$ Eukarpia must lie in the Sandykli valley, and no other site can be fuund on the ruad. The accompanying map shows that the necessary lines of the Roman roads here are confused in the Peutinger Table, the direct road from Eukarpia to Apameia being mixed with the road from Eukarpia by Eumeneia to Apameia.

XXXI.-Hieropotis was situated beside Kotch Hissar: the ruins are still considerable. On the north side there are remains of walls, built of large blocks of stone, probably of the original temple which formed the religious centre of the valley. This temple, if temple it be, is the only one I have seen in Asia Minor which appears to be older than the Graeco-Roman epoch: some excavation would be required before its character can be determined.

The evidence for the exact situation of Hieropolis lies entirely in the tale of Saint Aberkios ${ }^{2}$ and the relation of the city to the hot springs: they are about two miles south of Kotch Hissar, and are still a great medicinal resort. Kiepert acutely argued

1 To determine this was one of the first objects which Mr. Sterrett and I proposed to ourselves in out exploration of $18 s 3$.
$=J$. H. S. 1882 . 
from the name that the town must have been situated beside some natural phenomenon, and conjectured that the site was at the hot springs now called Gejek Hamam, about eight miles north-east of Afiom Kara Hissar.

Hieropolis must undoubtedly have been originally the chief place in the valley: the population dwelt scattered over the whole country, the priests of the central hieron ruled them, and around the hicron grew a town, Hiero-polis: though no express evidence of this period is preserved, yet the analogy of other districts is convincing. Hence, according to Ptolemy (quoted LXV)

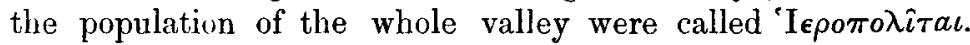
Auother evidence that the name Hieropo'is (or, as the Greeks preferred, 'I $\rho \rho a$ I Ió $\lambda_{l \varsigma}$ ) was extended over the whole valley lies in a passage of Strabo hitherto not understood (p. 374): $\tau \grave{a}$

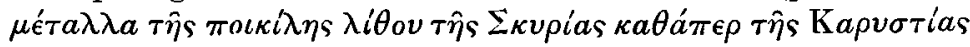

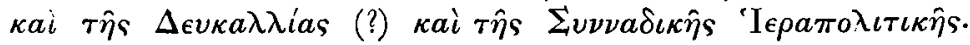
Meineke would expunge the last word, but such an alteration cannot be accepted. $\triangle E Y K A \wedge \wedge I A C$ must be corrected $\triangle O K I-$ MAIOY, ${ }^{1}$ and $\Sigma v \nu \nu a \delta \iota \kappa \hat{\eta}$ is perhaps to be explained as a gloss

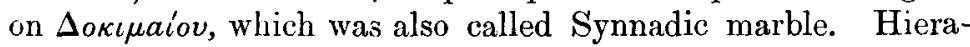
politic marble was perhaps found in the almost unknown mountains between Hieropolis and Synnada: the other Phrygian city, Hierapolis on the Lycus, is not likely to be meant, as marble in that neighbourhood could hardly have escaped attention in modern times. It is also possible that Strabo used the expres-

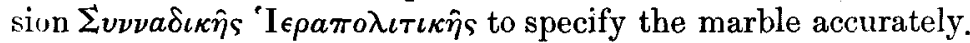
I shall show below (XXXVI.) that Synnada was the central office for managing the Phrygian marble trade.

These references to Hieropolis, and the important remains of the city, make it difficult to accept the conclusion that it alone of the five cities struck no coins. I have bought in the neighbouring villages three coins, all bearing the legend IEPOחO^EI$T \Omega N$, and all of the third century: besides these, I saw or bought in the neighbourhood coins of Eukarpia, Otrous, Stectorion, and Brouzos, also of Metropolis Phrygiae, of Synnada, of Eumeneia, of Apameia, and only one of Laodiceia. This statement shows how improbable it is that three coins of Hierapolis

1 The first corruption was $\Delta E Y$ $K A \wedge \wedge \mid O Y$, and then the gender wis corrected: on the form sorimaiou

H.S.-VOL. VIII. see Strab. p. 577. Hierapolitan marble, Const. Porph., Cerimon., p. 644. 
ad Lycum, all bearing the very rare form of the name as Hieropolis, should have been found beside the site of this other Hieropolis. The type on one of these coins moreover is, as M. Waddington informed me, identical with that of a coin of Brouzos in his collection. This fact is conclusive. The rule, then, seems clear : coins of the third century, IEPOחO $\triangle E I T \Omega N$, are to be attributed to the city of the Pentapolis. There are also some early coins with the same legend: these belong to Hierapolis ad Lyeum. Where Greek language and civilization had fully established itself, the name is ' $I \epsilon \rho a{ }^{\circ} \Pi \dot{b} \lambda_{\iota s}$ : the name

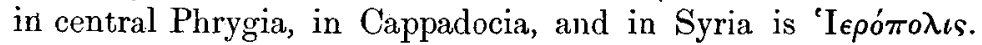
Hierapolis on the Lycus fell entirely under Greek influence in the first century of the Empire.

XXXII.-STectorion. The site of this town is fixed at Emir Hissar by the passage in Pausanias (x. 27. 1): toútov [i.e.

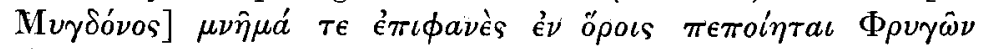

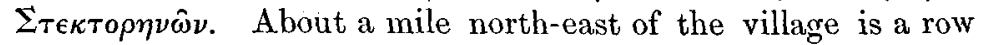
of tumuli on a ridge. One of them is very large, and is a conspicuous object in the view from most parts of the valley. I suppose that this is the tomb of Mygdon. The actual site of the city is at the village Emir Hissar, and the acropolis is on a little hill on the north side: the walls can be traced in the greater part of their circuit. The ruins of the city have suffered severely since Hamilton (ii. p. 169) visited them; when they were so perfect that a plan of the whole town might have been made.

XXXIII.-OTRous. It seems hardly credible that three distinct cities and bishoprics should have existed so close together as Emir Hissar, Tchor Hissar, and Kotch Hissar, but the remains at all three places prove the existence of cities of which that at Tchor Hissar-at present a village of one or two houses onlywas the smallest. The name Otrous is appropriated to this site by the following inscription, on a large basis in the cemetery at Tchor Hissar, which I copied in October, 1883 :-

\section{A $\triangle E Z A N \triangle P O N M A K E \triangle O N A$ KTICTHNTHCMOAEهC

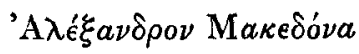 $\kappa \tau i \sigma \tau \eta \nu \tau \hat{\eta} \varsigma$ Tód $\epsilon \omega \varsigma$}

It is impossible to interpret this inscription as raised under the Empire to commemorate a patriotic fiction that Alexander the Great had founded the city: the Macedonian conqueror 
would not have been styled simply Alexander the Macedonian. There can be little doubt that this Alexander is the same who is mentioned on coins of Otrous about $200-215$ A.D., with the legend :

\section{A^EZAN $\triangle P O C$ ACIAPXHC ANEOHKEN OTPOHN口N.}

Alexander was a wealthy native, who filled the high-priesthood of Asia, and brought his native city into the knowledge of the world. He probably contributed the expense of striking the first coinage of Otrous, ${ }^{1}$ thus marking its claim to be a city, and was therefore honoured with the title "Founder" in this inscrip-

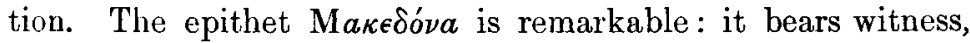
perhaps, to an attempt to concoct a pedigree for Alexander. The anxiety of Anatolian cities to connect themselves with ancient Greek history or legend is attested by many examples: many Macedonian colonies had been planted by the early Diadochi in Phrygia, c.g. at Peltae, Dokimion, Kadoi, \&c. It was therefore intended to flatter Alexander by representing him as of the true European lineage.

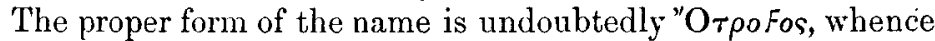
the adjective 'Orpo Fqvós: the town is named after the Phrygian hero Otreus, in whom G. Curtius long ago recognized the Greek hero Atreus (Griech. Etymol. ii. p. 293). Otreus and Mygdon were the Phrygian chiefs who fought against the Amazons on the banks of the Sangarios (Iliad iii. 186), and it is certainly remarkable to find "Otpo Fos, the city of Otreus, and Stectorion, the city where Mygdon was buried (Pausan. x. 27, 1), side by side in this valley. Otreus was known also in Mysia (Strab.

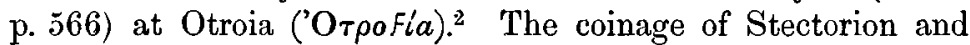
Otrous also bears witness to the survival of ancient Phrygian heroic legend in the valley: in both places a remarkable type occurs: ${ }^{3}$ (1) at Stectorion, "Héros casqué et cuirassé allant à gauche en retournant la tête et posant le pied droit sur une proue de navire: de la main droite il brandit une arme et de la gauche

1 Compare the account of the coinage of Peltae, given in my 'Antiquities of Southern Phrygia and the Border Lands,' which will shortly appear in the American Joumal of Archaeology.

¿ Plut. Luteull. has 'Orpúal, where $v$ is probably a misspelling (com. mon among late scribes) of ot, so that the word ought to be 'Orpoial.

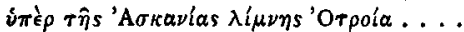

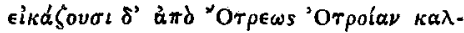

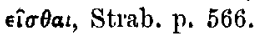

3 Imhoof-Blumer, Monn, Gr. p. 412: Mionnet s.v. Otrous. 
il s'abrite de son bouclier ;" (2) at Otrous, "Héros se retournant, le pied droit sur une proue de vaisseau, la main droite levée, et tenant dans la gauche la haste." Imhoof-Blumer and Head suggest the name Mygdon for this hero, but it appears to me that the name must be given according to a coin of Otrous, representing Aeneas armed bearing Anchises on his shoulders and leading by the hand the young Ascanios, towards whom he turns his head. The interpretation of the last coin is certain, and hence in the other we are not justified in seeking an otherwise unknown native legend, but we must find the Greek literary legend of Aeneas leaving Troy : the love of the Anatolian cities for introducing Greek legend, and the evident contempt of the Phrygians and Lydians for native legend, have been noted by me frequently. We see, then, in this district a cultus of Otreus, Aeneas and Ascanios, essentially the same as that implied, by Strabo (p. 566) at the lake Ascania.

An inscription which $I$ found in the mosque at Kelendres must be left in the same doubt as when I first published it ${ }^{1}$ :

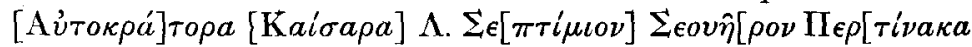

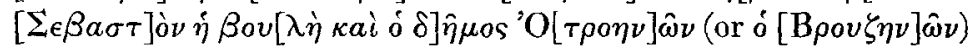

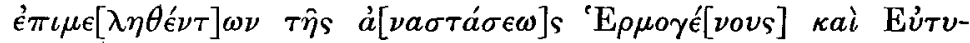
$[\chi \iota a \nu]_{o \hat{\nu}} \tau o \hat{v} \kappa a i[\ldots .]. v \nu \tau a \nu a v\left[\hat{a} \rho \chi^{\prime} \nu\right] \tau \omega \nu$, but the former restoration suits the space much better.

XXXIV. Brovzos.-The name is fixed at Kara Sandykli by the following text on a basis standing in front of the mosque

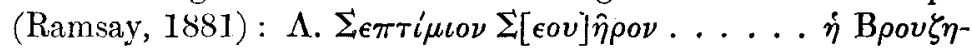

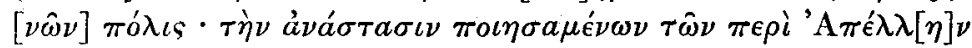

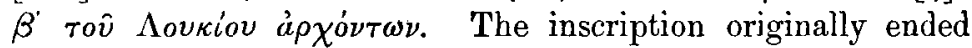
thus, but the other archons apparently desired to have their names recorded, and a new hand added кai $\Sigma \kappa \epsilon[\iota \pi] \iota \omega \nu \circ \beta^{\prime} \kappa a i$

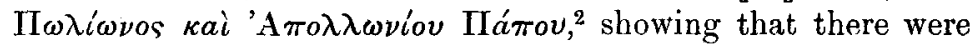
four archons at Brouzos. The name, according to Fick's canon, is for Broughos, which is perhaps a formation from $\Phi \rho v \gamma_{-}-\epsilon$ through Фpovyos.

An easy araba road runs from Akmonia up the Ahat Keui

1 Trois Villes Phrygiennes, p. 517:

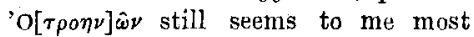
jrobable, on account of the small space remaining in the line to receive the nissing letters.

2 Two other insctiptions of Brouzas ate published in my Trois Vittes Phry. giennes. One contains the remarkable

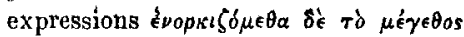

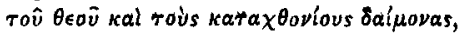

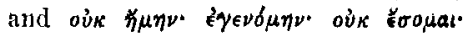

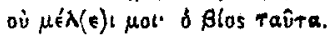


water, and down the Aram Tchai to the Pentapolis. That an imperial Roman road such as those of the Peutinger Table existed along this track is not probable; but the remarkable type on coins of Akmonia and Brouzos, Zeus slaying two giants, bears witness to intercourse between the two cities. ${ }^{1}$

In the rest of Phrygia Salutaris, it is not convenient to follow the order of Hierocles. There still remain some serious difficulties in the topography, and it is impossible to face these until we have first placed those about which definite evidence remains. After placing the cities whose situation is certain, we narrow the question about the rest.

XXXV.-Srnnada. The site was first proved by M. Perrot in the Revue Archéologique, 1876, from inscriptions copied in the town of Tchifut Cassaba ("Jews' Market") by M. Choisy. All previous conjectures had been far wrong. I need not repeat what M. Perrot has there stated as to the history of Synnada.

Study of the geography of the district shows that Synnada lies off the direct line of the great eastern highway: the easy road runs straight from Metropolis to Lysias, while tbe detour by Synnada leads over a decidedly more difficult country. Hence Synnada is omitted by Artemidorus and Strabo (p. 623) in the sketch of the great highway.

The Romans, who made Synnada the central city of a dioecesis, introduced it also, against the nature of the country, into their road-system. No straight road is possible from Apameia to Synnada, or from Metropolis to Synnada: only a difficuit mountain-path leads from Metropolis to Atlü Hissar. The main highway to the east has a singularly easy route through a mountainous country, by Metropolis, Euphorbium, Kinnaborion, and Lysias: it will some day be the line of a railway.

For a short time during the first century before Christ, when the pirates made the voyage along the south coast of Asia Minor unsafe, the Roman governors of Cilicia landed at Ephesos and made the journey along the eastern highway to Tarsos. They were thus obliged to pass through Laodiceia and Apameia, and not far from Synnada: it was therefore arranged that they should hold the conventus of Kibyra, Apameia, and Synnada (to

${ }^{1}$ See Imhoof-Blumer, Zcitsch. $f$. Numism. 1885, and Waddington, Voyrrge Numismatique. These monn- tains, over which an easy road passes west and east, are impassable north to sonth. 
which we may safely add Philomelion ${ }^{1}$ ) as they passed, and that the Kibyratic conventus sbould assemble in Laodiceia, which became henceforth the chief seat of that dioecesis.

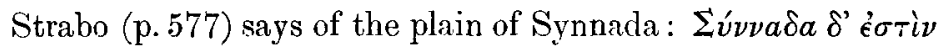

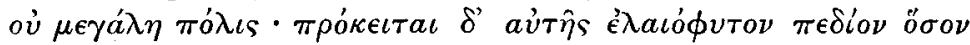

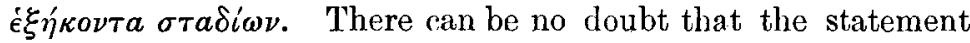
about olives was never true. Olives can never have been cultivated in the high plain of Synnada (3,400 feet above sea-level). Olives at the present day are cultivated for commercial purposes only in the lower Maeander valley: even in the Lycus valley they are said not to flourish, but above this they are almost unknown. Probably Strabo's text should be corrected to [a $\mu \pi] \epsilon-$ $\lambda o ́ \phi v \tau o \nu:$ his general accuracy in regard to Asia Minor leaves me no hesitation in dismissing the idea that he made an error in such a point.

XXXVI.-Dorimion. The site is assured by the proximity of the Dokimian marble quarries, which lie beside the junction of the two streams flowing past Seidilar and Itchja Kara Hissar, about two miles from each. Texier and Hamilton have both placed Dokimion correctly at Itchja Kara Hissar.

I have discarded the common view derived from the appersance of the roads in Tab. Peut., that a Roman road ran from Dorylaion and Nakoleia by Dokimion and Synnada to Apameia. Such a road can hardly bave existed, owing to natural difficulties between Nakoleia and Dokimion, and is certainly not wanted alongside of the other road from Nakoleia by Konna to Apameia. The Peut. Tab. really gives two roads-Dorylaion-Amorion and Synnada-Dokimion-Amorion, which, in the distorted representation of the country, look like a single road.

The administration of the marble quarries of Dokimion, which belonged to the emperors, is a difficult subject. I have elsewhere ${ }^{2}$ suggested that the name Synnadic marble, by which Dokimian marble was known to the Romans, must have arisen because the central office for administering the Phrygian marbles was situated at Synnada, and that communications about the marbles passed between Rome and Synnada. Western peoples ordered the Phrygian marble from Synnada and called it Synnadic marble.

1 Marquardt is not quite certain whether Philomelion was the seat of a conventus.
2 'Inscriptions Inérlites de Marlures Phrygiens,' in Mélanges d' Archeol. et de Ling., Rome, 1882. 
The procurator marmorum, a freedman of the emperor, resided at Synnada, and a subordinate office-that of the actual contractor for the works, or of the officials charged with the cutting (cassura)-existed at the quarries themselves. In the time of M. Aurelius we learn of procurators of Phrygia, imperial freedmen, also probably resident at Synnada. It is possible that the latter belong to a reorganization of the entire fiscus in Phrygia, which placed the administration of all imperial revenues, including the marbles, the estates, and other sources, in one central office. This is of course a mere hypothesis, propounded to guide future study towards its proof or disproof: according to the hypothesis the procuratores marmorum were superseded by procuratores Phrygiae about A.D. 160. The following procurators are known :-

1. [M. Ulpius] Marianus Aug. lib. proc., on two inscriptions of Synnada (Eph. Epigr., 127 and 128 ; Inscript. de Marb. Phryg., 1 and 2). His name gives his approximate date 110-130.

2. Irenaeus Aug. lib. procurator, on two blocks of Synnadic marble at Rome, date A.D. 137 (Bruzza, Annali, 1870, No. $258-9)$.

3. M. Aurelius Aug. lib. Marcio, procurator marmorum, who afterwards became procurator of Britain, and finally procurator Phrygiae, known from an inscription of Trocnada, or Tricomia (C.I.L. iii. 348).

4. Aurelius Aristaenetus, proc. Phrygiae, on an inscription of Synnada (Perrot, Rev. Archéol., 1876, p. 198).

5. M. Aurelius Aug. lib. Crescens, procurator Phrygiae, known by a Greek inscription of Eukarpia (C.I.G., 3888, where it is falsely ascribed to Eumeneia).

The subordinate office at Dokimion is implied in the following quarry-marks on blocks of marble found there:-

\begin{tabular}{|c|c|c|c|}
\hline OFFicina? PELAgii & A.D. $14 \check{\partial}(E p h$ & Epigr.) & No. 114 \\
\hline OFFIcina? [PELAgii] & A.D. 146 & $"$ & 115 \\
\hline OFFicina? PELAgii & A.D. 146 & " & No. 1381 \\
\hline OFFicina? ASIATici & A.D. 147 & $\mathrm{~N}_{0}$ & o. 116 \\
\hline OFFicina? ASIATICi & A.D. 164 & $"$ & No. 118 \\
\hline CAESura DOMitii? & A.D. 164 & " & No. 118 \\
\hline
\end{tabular}

With regard to the quarries, we find Brachium SECundum, Brachium TERTium, Brachium QVARTum. 
The symbol REPR in five inscriptions, which I interpreted repr(obatum) [non sine aliqua specie veri, Momms.], is perhaps REPR, badly formed and badly spelt, for B. Tert. : quarry-marks are singularly rudely and even falsely scratched on the blocks.

The marble quarries of Dokimion were still rich in A.D. 414 (Cod. Theodos., xi. 28, 9).

The distance (xxxii.) on the Peutinger Table between Dokimion and Synnada is true if we assume it as the sum of the distances Dokimion-Prymnessos (xvii.) and Prymnessos-Synnada (xv.). The accompanying map shows the line of the road by which the vast blocks of Dokimion marble (Strabo, p. 577 ) were carried to the sea. This road does not touch the town of Synnada, but passes through its territory.

In the later Byzantine time Dokimion was separated from Phrygia Salutaris, at the formation of a new ecclesiastical division under Amorion as metropolis. This was perhaps coincident with the formation of the Khonai metropolitan district, ${ }^{1}$ though the fact is not recorded. This suspicion is roused by the following facts:-(1) The only reference to the advanced dig-

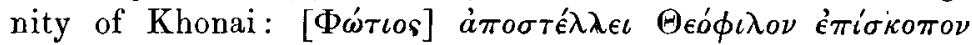

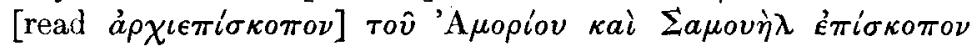

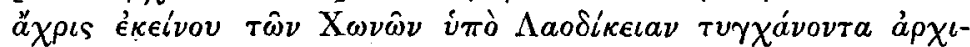

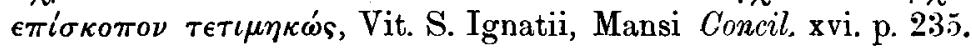
(2) The early Notiitae VII., VIII. IX., give Amorion as a bishopric under Pessinus, and arrange its dependent bishoprics in the same way as Hierocles, whereas Not. I., III., X., XIII., give the following list:-

\begin{tabular}{|c|c|c|c|}
\hline 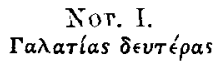 & Not. III. & Nor. $\mathrm{X}$. & $\begin{array}{c}\text { Hieroules } \\
\text { Not. VII. VIII. IX }\end{array}$ \\
\hline 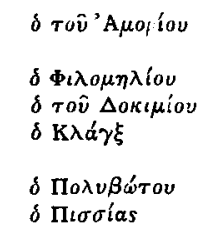 & 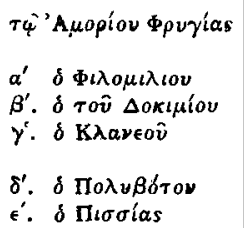 & 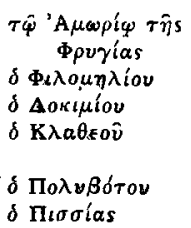 & $\begin{array}{l}\text { Galatia Salutaris } \\
\text { Pisidia } \\
\text { Phrygia Salutaris } \\
\text { K } \lambda \text { d́ves Galatia } \\
\text { Salutaris } \\
\text { Phrygia Salutaris } \\
\text { Not mentioned }\end{array}$ \\
\hline
\end{tabular}

${ }^{1}$ About 859 A. D. or soon after. 
Such a contradiction among the Notitice points to a change in the middle of the ninth century, if we could feel any confidence that it was entered immediately in the lists. (3) In Concil. Nicaen. II., A.D. 787, Amorion is ranked as autokephalos, coming at the very end of the list of superior bishops, and just before the list of ordinary bishops begins. It had therefore been already raised to independent ecclesiastical rank, whereas in 692 it ranks as an ordinary bishopric subject to Pessinus. But even in 787 it is only autokephalos, not a metropolis: Dokimion, Klaneos, Philomelion appear in their proper provinces. At last, in the Council of 879 , it appears as a metropolis, with Pissia dependent on it.

This Amorian dioccesis is a well-marked district, within which we must not look for any of the other Phrygian bishoprics, and the order in Hierocles proves that the names $\mathrm{K} \lambda \hat{\eta} \rho \rho^{\prime}$ ' $\mathrm{O} \rho \iota \nu \hat{\eta} s$,

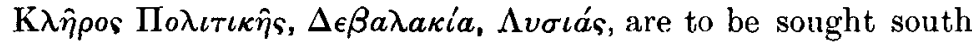
of this district, towards Synnada and the Pisidian frontier. The importance of this inference will appear below.

XXXVII.-Prymnessos. The site of this city was long sought in vain. Franz and Kiepert placed it at Seidi Ghazi on the evidence ${ }^{1}$ of an inscription found there, engraved on a buge block of marble by the Prymnessian people. In my paper, "Prymnessos and Metropolis," I argued, from a false interpretation of the following inscription, ${ }^{2}$ that Prymnessos was in the valley of Bayat: [Imp. Caesari L. Septimio, \&c.] a Prymnesso IIIr. In the first symbol of the number the engraver has distinctly cut not I, but $A$ : this, combined with the blurred surface, made me understand $[\mathrm{M}] \mathrm{I} \Gamma$, and look for Prymnessos thirteen miles away. In reality this milestone is the third from Prymnessos, and just three miles south of the bridge in which it is now built are the ruins of a city which was important enough to possess a small theatre. The ruins are situated beside the village of Seulun : the main road from Afiom Kara Hissar to Tchai and Ak Sheher passes through them, and it is almost incomprehensible how they escaped notice till October, 1883. This road is one of the most important routes in the country, and even at the present day an observant eye detects the signs of an ancient city on the actual road, though the theatre is not in sight from the road. After discovering the city, and recognizing at once that it must,

$$
1 \text { C.I. G., } 3818 .
$$

${ }^{2}$ Eph. Epigr., 176 ard 1466. 
be Prymnessos, I went to verify the milestone quoted above, and saw the true reading.

XXXVIII.-Kone, Konna was situated, according to the Peutinger Table, between Nakoleia and Eukarpia, on the road leading from Dorylaion to Apameia. There can be no doubt as to the course of the road from Dorylaion to Apameia. It ascends the river Parthenios to its source, descends a tributary of the Adji Su, and passes by Kidyessos into the Pentapolis. Between Nakoleia and Kidyessos it passes two ancient sites-the first at Kumbet, the second near Beuyeuk Tchorgia. To determine which of these is Konna, we have to look at the Byzantine lists.

XXXIX.-MeTropolis is mentioned by Hierocles between Dokimion and Meros. The Notitiae do not contain the name,

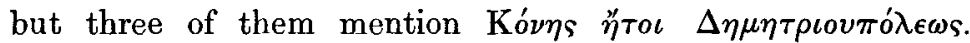
Demetriopolis is the "city of Saint Demetrios." It is well known that the goddess Demeter was often transformed into the Saint Demetrios, and in this case obviously the Meter Goddess has suffered the same transformation: Metropolis and Demetriopolis are the same place.

Kone and Metropolis were therefore situated near each other, and were united under the charge of a single bishop. The order of Hierocles here is important : he enumerates Polybotos, Dokimion, Metropolis in a line going westward, and then turns north to Meros and Nakoleia.

XL.-Ambason is mentioned by Steph. Byz., "A $\mu \beta a \sigma o \nu$, $\mathbf{M} \eta \tau \rho o ́ \pi o \lambda \iota s \tau \hat{\omega} \nu \Phi \rho v \gamma \hat{\omega} \nu$. It is probably identical with a place 'A $\mu \pi \circ \hat{v} \nu$, mentioned on the road leading from Iconium past Afiom Kara Hissar towards Constantinople by Anna Comnena in her account (Book xv.) of her father's expedition against Iconium.

Alexius Comnenus, hard pressed by the Seljuk army in the plain south of Polybotos, avoided the road via Dorylaion by which he

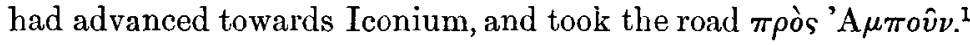
This latter road must obviously be the alternative route to Constantinople by way of Kotiaion, and the name "A $\mu \beta a \sigma o \nu$ or 'A $\mu \pi$ ov̂ $\nu$ appears to be still preserved as Ambanaz, a village on

1 It is remarkable that the historian specifes the road by such an unimportant name as 'A $\mu \pi 0 \hat{v}$, when well-known

cities existed on this well-known and frequently used road. 
the road in question, and situated in the same valley with Tchorgia. Ambason (i.e. Metropolis) and Kone must therefore lie in the valley north of Afiom Kara Hissar.

Stephanus, in the entry quoted above, need not necessarily be understood as implying that Ambason and Metropolis are two names for one town. He is probably quoting from a statement (such as we often find in Byzantine documents ${ }^{1}$ ), ${ }^{\prime} \mathrm{A} \mu \beta a \sigma o \nu \dot{\eta}$ $\nu \hat{v} \nu \mathrm{M} \eta \tau \rho \operatorname{or} o \lambda \iota s$, which does not imply that the two names denoted exactly the same place. Accordingly Kone, Metropolis, Ambason, were three small towns in the same neighbourbood.

It is, I think, possible to go further and specify the exact situation of Kone and of Metropolis, as we have done for Ambason. The remains of Byzantine life, and especially the rock-cut churches, at the village Ayaz Inn ("Caves of Hoar Frost"), mark it as a place of importance in Christian time: on the other hand, the remains of Roman life are unknown at Ayaz Inn, but are found about Tchorgia. Kone was the more important place in the peaceful Roman time: it lies in the open plain near Tchorgia. Metropolis became more important when the country was subject to the inroads of Sassanidæ and of Saracens : it lies in the hills at Ayaz Inn. The process whereby typical Roman sites were gradually abandoned in favour of safer sites in secluded positions is one to which $I$ have frequently to call attention.

This account of Metropolis is sufficient to prove that no coins can be attributed to it (see below, LXXXVII.). Coins of Konna might, however, be expected : their absence suggests that it was, under the Empire, not autonomous but subject to Prymnessos (see LXVI.). The coins of Prymnessos bear the head aud name of $B A \Sigma I \Lambda E Y \Sigma M I \triangle A \Sigma$, which refers to the remarkable series of early Phrygian monuments close to the site of Metropolis.

XLI.-Acroenos. This name occurs with the variants Acronios, Acroinos, Acrounos. ${ }^{2}$ I have in an old paper given in detail the evidence which proves that the impregnable castle of Kara Hissar was the fortress Acroenos, so important in the

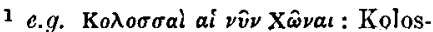
sai and Khonai are two different eities, near each other: the latter in late time supplanted the former.

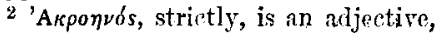

and oceurs as such in the Tekmorian in-

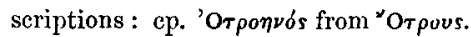
The name refers to the remarkable rock (Greek à kpós). 
Byzantine wars, ${ }^{1}$ and need not here repeat it, as it involves a study of two different campaigns-in 739 and 1117. The earliest reference to Acroenos is in A.s. 716, but it must have existed as a fortress before that time. As soon as foreign invasion began to sweep over the country, the situation of Acroenos, on a column of volcanic rock rising sheer out of the plain to a height of nine hundred feet, must have made it a tower of strength for the country round.

XLII.-NICOPol.s is mentioned in Notitiae VII., VIII., IX., and I. I have (l.c.) shown that this is probably the name given to the castle of Acroenos in commemoration of the great victory of 739, a turning-point in the struggle against the Arabs. This Greek name, like many others of the kind, gave place to the native name in later tirnes : in the last Notitiae III., X., XIII., we find no Nicopolis, but Acroenos. When this fortress first became a city and bishopric, it was put at the end of the list with Kone and Skordapia, which are in the same district; but as it must have steadily grown in importance, till it is now one of the chief towns of Anatolia, we find it in the late lists placed fourth in order, immediately before the neighbouring city Prymnessos. In these later lists $I$ feel certain that the correct entry would be

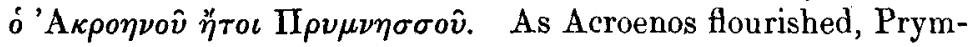
nessos must necessarily decay; and there are various examples of the retention of a bishopric in the ecclesiastical lists after its place had been taken by another city. Thus Perga remains after Attalia had become the first city of Pamphylia and seat of the archbishop; ${ }^{2}$ and Pessinus was merged in Justinianopolis (Sivri Hissar). ${ }^{3}$

XLIII.-Paroneios Phrygia. The region so named has never yet been accurately specified. Strabo's language (p. 576) describes the long valley which extends along the northern side

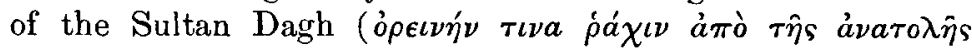

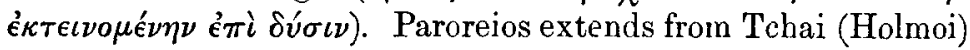

1 'Prymnessos and Metropolis,' in Mittheil. Athen., 1882. In this, my first attempt at reasoning on Phrygian topography, with only a hurried glance at the district to work on, and encumbered by the traditional misconception as to the road from Nakoleia to Synnade, I am pleased to be able to quote the discussion of the site of Acroenos as conclusive, and to confirm by fresh reasons the situation assigned to Augustrpolis.

${ }^{2}$ See my paper "Antiq. of S. Phry" gia and the Border Lands.'

${ }^{3}$ As I shall prove in a fortheoming study of Galatia. 
to Ilghin (Tyriaion); it stretches north-west to south-east between Sultan Dagh and Emir Dagh.

Strabo (p. 576) gives a list of the districts and cities of Phrygia Magna; he uses this term in the ancient sense, as distinguished from Phrygia Epiktetos and Phrygia Hellespontiaca, not in the later Byzantine sense (see XXVIII.). Phrygia Magna

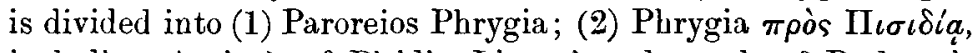
including Antioch of Pisidia, Limnai, and much of Ptolemy's

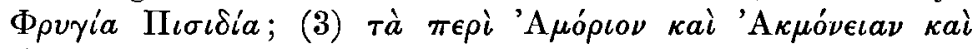

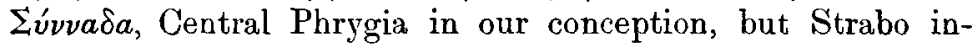
cludes all Northern Phrygia in Epiktetos or in Mysia; (4)

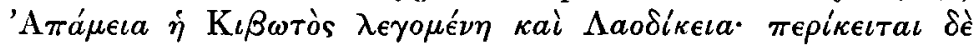

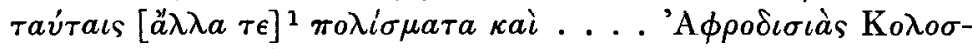

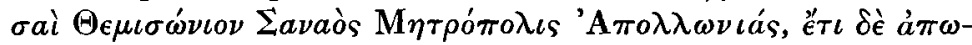

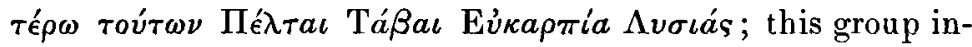
cludes the southern and south-western part of Phrygia, with which Strabo included the plain of Tabae. ${ }^{2}$

This entire list is clear and well arranged, if we remember that Blaundos is reckoned to Lydia (not, with the numismatists, to Phrygia), that Trajanopolis and Temenothyrai belong to Strabo's Maionia, and that Kadoi, Ancyra, and Synaos belong to his Mysia. One correction of the text, however, has been required, AKMONEIAN for $E Y M E N E I A N$; the latter word disturbs the order, and renders unintelligible the whole list. No writer could place Peltae and Eukarpia in one district, Eumeneia in another.

It shows the obscurity of Phrygian topography that Paroreios, a district which is so clearly marked by nature and by ancient writers, should never yet have been correctly defined. Its chief cities are Polybotos, Julia, Philomelion, ${ }^{3}$ Hadrianopolis, and Tyriaion; it extended, according to Strabo, from Holmoi (Tchai) to Tyriaion.

XLIV.-Polybotos. The accusative חlo $v^{\beta} \beta$ orov is still in use, as Leake observed, under the form Bolowodun, the name of an important town, the seat of a kaimakam, on the horse-road

1 The insertion is nine.

2 Yet in 570 , using a different authority, Artemidorus, he places Tabae in Pisidia. Tabae is perhaps corrupt in the passage in the text above.

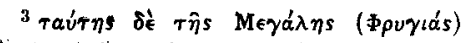

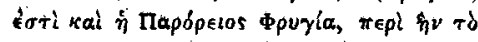
$\Phi เ \lambda o \mu\{\lambda \iota \sigma$, Eustath. ad Dionys. Perieget. 815. 
from Constantinople by Eski Sheber to Konia; this road was one of the most important in Asia Minor from the foundation of Constantinople till steamships recently superseded land roads as the means of communication between the capital and the south coast of Syria and Cyprus. Before Constantinople was founded, Polybotos lay off the main road and was an unimportant place, while Julia, in the same plain further south, was the chief city.

XLV.-JULIA. This city was situated between Philomelion and Synnada, and it struck numerous coins from Tiberius to Valerian. The distance from Philomelion is given in the Table as xxxv. miles, and from Synnada as xxxii.; one or other of these numbers must be wrong, as the total is too great. ${ }^{1}$ Kiepert places Julia at Tchai, and this cannot be far wrong. I should however look for a site nearer Sak!i, correcting the distance from Philomelion to xxiv., and reading the whole road Philonclinm xxiv. Julia xii. Lysias xxiii. Synnada xxviii Metropolis xxviii. Apameic. My reasons are: (1) some ancient city must have existed in the wide and fine plain between the lakes Eber Göl arid Ak Sheher Göl; (2) Sakli is an important market town, and the seat of a mudir; (3) Sakli is on a road which was important both in modern times and under the Roman Empire; (4) the modern boundary betweeu the vilayets of Konia and Brussa lies sonth of Sakli : it is probable that the boundary has descended from Byzantine time, and that it was the boundary between Salutaris and Pisidia; ${ }^{2}$ (5) Sakli is in Paroreios, and Julia-Ipsos is one of the few cities which may bave been in Paroreios; (6) Tchai is more difficult to reconcile with the Peutinger Table's numbers.

XLVI.-IPsos was the scene of the decisive battle fought in 301 B.c. by Antigonts against Seleucus and Lysimachus. Antigonus had wintered at Synnada; in the spring he marched eastwards with the view of preventing a junction between the forces of his two antagonists. Seleucus, coming from Syria, and Lysimachus, coming from the Hellespont, naturally met in the plain that stretches between Sakli and Bolwadun.

1 Synnada to Tchai 9 hrs., Tchai to Philomelion (Ak Sheher) 9 hrs.

2 These provinces disappeared, politically speaking, lonir befor'e the 'Turkish power began : but ecclesiastically, they lived as long as the Church organization livel. 
Ipsos is never mentioned under the Roman Empire, but is known under the Greek kings and as a Byzantine bishopric; Julia is mentioned only under the Roman Empire, and yet it was an important city with rich coinage. Ipsos and Julia were in the same district, and the conclusion is inevitable that the name Julia superseded Ipsos under the Romans, but that before Hierocles the old name had once more come into use.

XLVII.-Philomelion has been proved at Ak Sheher by Hamilton. It was in all probability a foundation of the Diadochi, otherwise it could hardly have been omitted by Xenophon. It was therefore an obscure town or village tiil some of the Syrian or Pergamenian kings took advantage of its fine situation to found there a great Greek city with a Greek name. It was the seat of a conventus (see XXVIII.).

XLVIII.-HADRIANOPOLIS was situated on the direct road from Philomelion to Ikonion, at or near Doghan Hissar (Cinnam. p. 42).

XLIX.-Thymbron, according to the route of Xenophon, must have been near Doghan Hissar. It was still a city in the time of Pliny, but does not occur later. These facts show that it was the town which was refounded by Hadrian under the name Hadrianopolis.

L.-Tyriaion has been proved by Hamilton at Ilgin. I believe that the Tyriaion of Xenophon's time was situated between Ilgin and Khadyn Khan, and that buge lines of embankment and sculptures in Syro-Cappadocian (Hittite) hieroglyphics mark the site.

LI.-The city which Xenophon means when he speaks of Kav́orpov $\Pi \in \delta i o \nu$ must be Ipsos. His distances are, starting from Apameia :

$\begin{array}{llllrl}\text { Peltai } & \mathbf{2} & 10 & 25 & \mathbf{8} & \text { Yaka Keui. } \\ \text { Keramon Agora } & \mathbf{2} & \mathbf{1 2} & \mathbf{3 0} & 9 \frac{1}{2} & \text { near Islam Keui. } \\ \text { Kaystrou Pedion } & \mathbf{3}^{1} & \mathbf{3 0} & 75 & 24 & \text { Sakli. } \\ \text { Thymbrion } & \mathbf{2} & 10 & \mathbf{2 5} & \mathbf{8} & \text { near Doghan Hissar. } \\ \text { Tyriaion } & \mathbf{2} & 10 & \mathbf{2 5} & \mathbf{8} & \text { near Ilgin. } \\ \text { Ikonion } & \mathbf{3} & 20 & 50 & 16 & \text { Konia. }\end{array}$

1 This must certainly be corrected to 5: no army could march 75 miles in three days, and it is clear that 12 to 15 miles

was the day's march, and a very good march it is. 
The fountain of Midas is, as Hamiiton saw, unmistakable; it is about five miles north of Philomelion.

LII.-Atgusropolis, as I proved in a former paper ${ }^{1}$ from the passage of Anna Comnena already quoted (see XL.), was situated at Surmene, nine miles E.S.E. from Afiom Kara Hissar. It appears in all the Notitiae, and in several of the Councils from 553 onwards, under this name. Such a city must, though omitted in the list of Hierocles, be concealed in it under another name.

The very name Augustopolis, applied to a place not important enough to coin money, and not found before the fifth century, rouses the suspicion that it gained its name from being an imperial estate; this suspicion long haunted my mind, and at last I discovered, in the tale of Saint Eutychius, ${ }^{2}$ a complete confirmation: he was born, A.D. 512, in Augustopolis, and the expression Oeia $\mathrm{K} \dot{\omega} \mu \eta$ (imperial estate) is used as another name for his birthplace.

LIII.-Kleros Oreines. LIV.-KLeros Politikes. The name $\kappa \lambda \hat{\eta} \rho \circ$ is often applied to an estate, and in these two cases it has probably that sense. There is only one kind of estate which could rank as a recognized separate and selfgoverning community-an imperial estate. In several other cases such estates appear in Hierocles' list, in Caria $\chi^{\omega \rho i a}$

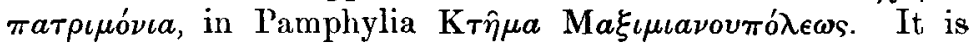
well known that imperial estates did exist in Phrygia, ${ }^{3}$ and we may therefore safely interpret these two Kleroi as two great imperial estates; one is 'the estate of the mountain land,' the other 'the estate of the city land.' 4

Horses from the Phrygian estates were highly prized, and ranked with the Cappadocian as the finest known. The Cappadocian estates are known to have been at Andabalis, near Tyana, and the horses reared there were called Palmatiani from a

1 I need hardly utter a warning against the error $I$ made in the same paper, in identifying Augustopolis with Metropolis: the false belief that Metropolis struck numerous coins, together with Professor Hirschfeld's erroneous view about the position of the southern Metropolis, which I could only accept implicitly, were sufficient to mislead me.

2 Act. Sanct., April 6th, p. 550.

3 Horses 'quos Phrygiae matres sacris praesepibus edunt,' Claud. ('sacris' denotes imperial property): cp. Cod. Theodos. passim.

${ }^{4} \chi$ ápas being understood: in Sparta

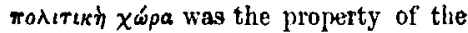
Spartiate community. 
certain Palmatius. The Phrygian horses were named Hermogeniani. ${ }^{1}$ In rearing horses in Asia Minor it is of the first importance to take them to very lofty pastures in the heat of summer; these were on the Klêros Oreines, and the two Kleroi were therefore both required for the one purpose, and were probably under one management. This fact makes it probable that the two $\kappa \lambda \hat{\eta} \rho \circ$ formed one estate, and were in the Notitiae grouped under the name Augustopolis.

In Not. III. both Augustopolis and Kleroi occur: I might quote a similar instance of double mention, and might show the exact year (879) when this error was introduced, but considerations of space forbid.

LV.-Trokonda. The demos of the Trokondenoi was situated somewhere near Augustopolis: it is mentioned only in an inscription copied by me in 1884 at the same bridge where the Prymnessian milestone still lies: the upper part of the stone, on which was sculptured a bust (of Zeus?) has been broken off :

\section{EIPHvalOC MHNOQI \\ nOY TOY ANII//////OC, HA。 OY $\Gamma A M P O C, \quad Y \Pi \in P$ DHMOU TPOKON $\triangle H N W N$ \\ $\Delta E I \quad E Y X H N$}

Trokonda is related to the personal name Trokondas, as Kidramos to Kidramouas, as Kadoi to Kadouas. It is possible that Trokonda was the early name of Augustopolis.

LVI.-Anaboura, LVII.-Alandri Fontes are placed on the direct road from Synnada to Pessinus, by which Manlius must have marched.

LVII.-LVIII.-BeUdos VETUs is placed with definite certainty by the reference in Livy xxxviii. 15 ; it was five miles from Synnada on the march towards Galatia. This brings us into the

1 Gothofredus, ad Cod. Theodos. vol. ii. p. 56A., promises the proof that Hermogeniani and Phrygiaci or Phrygisci were identical. I do not see that he has explicitly redeemed the promise; but the identitication appears necessary.

H.S. - VOT. VIII.
I should consider the simplest explanations of the names to be that Palmatius and Hermogenes were the respective lessees or managers of the Cappadocian and Phrygian estates in the latter part of the fourth century. 
hilly country between Synnada and Augustopolis, and the very considerable remains at the village of Aghzi Kara, "Black Mouth," must be assigned to Beudos Vetus. It is probable that BoudeIA, which is mentioned by Nonnus and by Steph. Byz., is another form of the name Beudos. This suggests the possibility that Phytia or Phyteia of the Notitiae may also be the same place. The variation in form is great, but names in their Byzantine dress have sometimes a strange appearance.

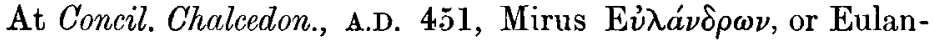
drae, or Eulandrorum, was present among the bishops of Phrygia Salutaris. He cannot be a bishop of Blaundos in Pacatiana, by mistake reckoned to Salutaris, for Blaundos was really in Lydia, and its bishop was present at the same Council. He must therefore be a bishop of some city of Salutaris whose name is corruptly written. The variant Mirus Bilandensis suggests the probability that Beudensis is the correct form. ${ }^{2}$ The order in which the names occur supports this hypothesis-Synnada, Beudos or Eulandra, Ipsos, Lysias-though much stress cannot be laid on the order in the ecclesiastical lists.

Beudos is related to Synnada as the older Phrygian city on the bills to the new Greek city in the plain: hence the epithet Vetus.

Beudos, then, is a city coining money in the second century after Christ, a bishopric in A.D. 451, and again in the Notitiae; it cannot, therefore, fail in Hierocles. Being a city which coins money, it cannot be identified with Kleros Oreines, though its situation among the hills would readily lend itself to such an identification.

LIX.-DeBalaAkia. The name, which is unknown except in Hierocles, is obviously corrupt. The district in which it must lie is narrowed by the results of our inquiry to the neighbourhood of Synnada or of Augustopolis. In this district we have just found that Beudos or Boudeia must have been known to Hierocles, and I shall now go on to prove that Kinnaborion also must have been known to him. I therefore suppose Debala-Kia to be a corruption of these two names.

3 Nonnus and Stephanus agree in Boudeia and Doiantos Pedion : probably Nonnus is Stephanus' authority.

2 The unimportant name Beudos has been assimilated by copyists to the wellknown Blandos or Blaundos : the letter $\rho$ often crept into the last syllable of the

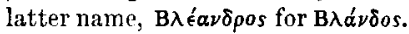


LX.-Kinnaborion is mentioned first in the inscriptions of

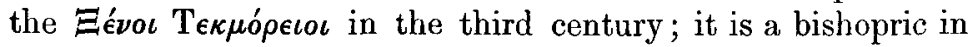
the Councils of 451 and 787 , and in the earlier Notitiae VII., VIII., IX., and I. These references prove an unbroken existence of a town of some consequence from 200 to 800 . Such a town cannot be unknown to Hierocles, and its apparent omission can be most easily explained by the supposition just advanced. A study of the Tekmorian inscriptions makes me place Kinnaborion in the south-western part of the Karamïk Ova, perhaps near Geneli, which occupies a fine situation, with a splendid fountain supplying a river that flows into the duden (katabothron) of Karamiik. ${ }^{1}$ The bishopric of Kinnaborion must have included the adjoining Oinan Ova.

LXI.-EUPHorbium is mentioned in the Peutinger Table on the road between Apameia and Synnada. If this table be correct, Euphorbium must be identified with Metropolis, and we might suppose that the whole plain was called Euphorbium, the inhabitants Euphorbeni, and the town Metropolis. ${ }^{2}$ This view is, however, irreconcilable with Pliny, v. 106, who mentions both Euphorbeni and Metropolitae in the conventus of Apameia. Hence it is more probable that Euphorbium is to be placed on the great eastern highway between Metropolis and Lysias, in the Oinan Ova; and the error, which this position presupposes in Tab. Peut., is due to the difficulty of representing the complicated roads in this district. ${ }^{3}$ The roads, then, are:

Apameia, xxvrr. Metropolis $\left\{\begin{array}{l}\text { xxvir. Synnada, xxIIr. Lysias } \\ \text { xII. Euphorbium, xxıv. Lysias }\end{array}\right\}$ xIr. Julia.

LXII.-Oinia, or OinaIos. The form is uncertain; the only

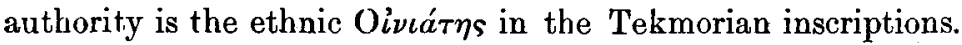
The name is still in use in the form Oinan, the name of a village and a small valley among the mountains of the Phrygo-Pisidian frontier. Remains of ancient life are abundant at Oinan. At

1 I have visited Geneli (few remains), and inquired as to the course of the stream which rises there.

2 The distances agree well with this view.

${ }^{3}$ The possibility must howerer still be left open, either that Pliny is wrong in distinguishing Metropolis and
Euphorbium (a supposition which is most improbable, considering that Pliny is doubtless quoting from a list of the conventus), or that these two cities were both in the same valley, and that later Euphorbium was merged in Metropolis. 
Aresli, two miles distant, I copied the following inscriptions in 1886.

\section{(1) ¿OYAIOC ACKAADOL EPMOKAHE EYTYXOY MEAITWN $\triangle A \wedge W N T O E$ IMAN LICINOY}

(2) complete at right and bottom, broken at top and left.

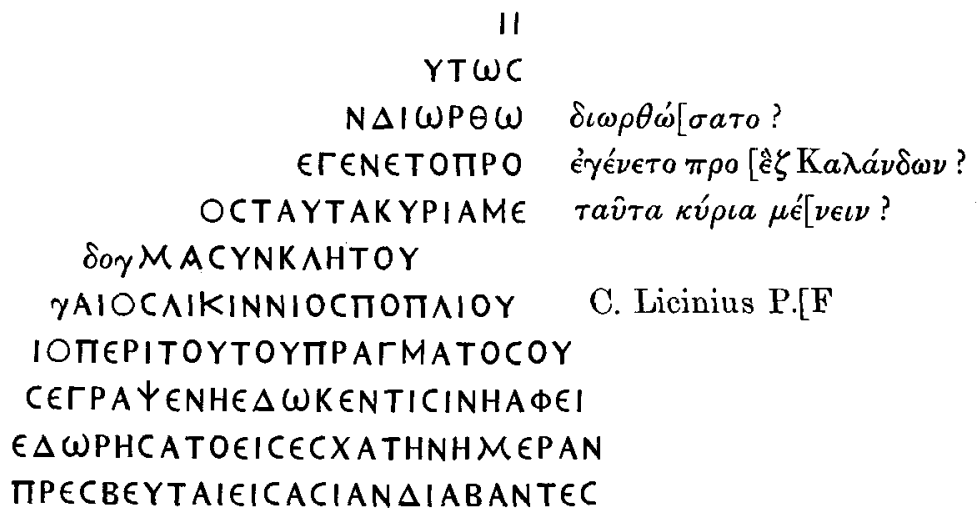

Euphorbium was perhaps the name of the whole plain, Oinia of the town.

LXIII.-_SibIDounda is not mentioned by Hierocles, yet it struck coins from Marcus Aurelius to Gordian, and is mentioned in all the Notitiae in forms more or less corrupt-Sibindos, Sinbindos, Sebindos, Sibildos, Siknodos. Sibidounda then was certainly a city in the time of Hierocles. It does not however occur either at any Council or in Hierocles; and this fact rouses the suspicion that it may be concealed under one of the names which occur in Hierocles and the Councils, but not in the Notitice, viz. Praipenissos and Amadassa. The former is impossible, and I therefore suggest the possibility that the people Amadasseis had in their country a city Sibidounda; at the same time $I$ am fully conscious of the want of reasons to support this view (see LXIV.).

LXIV.-Amadassa is mentioned Concil. Chalcedon. 451, Concil. Constantinop. 553, Concil. Nicam. II. 787, and in Hierocles 
under the corrupt form 'A $\lambda a \mu a \sigma o \hat{v}{ }^{1} \quad$ No other reference to the place occurs, and evidence as to its situation is therefore practically non-existent. All that can be said is, first, that it was a place of some consequence, being mentioned in $4.51,530,553$, and 787, and that it must therefore be mentioned in the Notitiae under some other name; while it cannot of course be identified with any name occurring in the same lists that meution it. These considerations appear to narrow us down to an identification with Sibidounda: we may suppose that the demos named Amadassa possessed a city named Sibidounda. The name Sibidounda occurs in the second century; then Amadassa takes its place from 451 to 787 ; finally corrupt forms of Sibidounda return in the Notitiae. Amadassa may be indicated by the corrupt

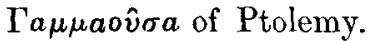

LXV.-Lrsias. About this city also hardly any evidence exists : if we could trust the conclusion of Droysen, ${ }^{2}$ that it was founded by some of the Diadochi, we should have to look for it on the line of one of the great roads, and probably on the great eastern highway. Beyond this we have only the order of Hierocles to guide us; he appears, in the four names, the Kleroi, Debalakia, and Lysias, to be in the neighbourhood of Synnada and Prymnessos, and thereafter he passes to the eastern frontier, with Ipsos and Polybotos. We also know from Strabo (p. 577, cp. XLIII.) that it was not in Paroreios. On these presumptions I have placed the name Lysias ${ }^{3}$ at Bazar Agatch, on the road from Synnada to Julia. Remains of ancient life are found there and at the neighbouring villages of Akarrim and Karadja Euren, and the character of the country suggests that a city of some consequence, such as might coin money, existed here. There is a duden here, through which the water of the whole valley from Geneli downwards disappears. The site conjectured by Kiepert, Khozrev Pasha Khan, is inconsistent with the order in Hierocles, and moreover I shall show that Kakkabokome was situated there.

I argue that, if Lysias was founded by the Diadochi, it probably stood on the eastern highway, on the following grounds: The

\footnotetext{
${ }^{1}$ Implying a transposition, Adamassos : cp. Kapatiana, Morea ( = Romaia),

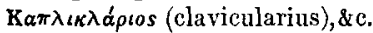

$=$ Gesch. d. Hellonismus.
}

3 I saw several coins of Lysias at Sandykli: this suggests a situation within easy communication of Synnada and the Pentapolis. 
cities on this road are almost all founded or refounded during the Greek or Roman period-Antiocheia, Laodiceia, Apameia, Synnada, Julia, Philomelion (see XLVII.), Laodiceia Katakekaumene, Archelais, Caesareia, the only important exception being Tyriaion; on the other hand, there is not a single foundation of that period on the older Royal road of Herodotus.

LXVI.-Meros is placed with confidence by the order in Hierocles on the road between Metropolis and Nakoleia at Kumbet. The situation is confirmed by Constantine Porphyr., ${ }^{3}$ who mentions it as the boundary between the Anatolic and Opsikian Themes. It appears to have been a place of small consequence under the Roman Empire, but to us it is interesting, as the monuments of the old Phrygian kings round the tomb of Midas are close to it. The mountains in which these monuments are situated, and in which some of the upper waters of the main Sangarios stream rise, were called Ballenaion (from Ballen, "king": Pseud. Plut., De Fluv.).

I give here the text of a fragment of inscription at Kumbet: I copied it first in 1881, but the faintness of some letters baffled me. M. Waddington pointed out the word $\mu \iota \sigma \theta \omega \tau \eta^{\prime} s$, and I have since re-examined the stone twice, verified the word $\mu \iota \sigma \theta \omega \tau \eta$ 's, and recovered the general sense of the whole.

\author{
JYIAI \\ MANIKC \\ -HC $\supset K A I \Delta H$, \\ دHMOYNAK / \\ AППAMIC $\Omega \bar{H}$ \\ OYKAICAPOCFEAY \\ $\triangle \Omega$ sTKATACKEYHNC \\ $\Omega N I \Delta I \Omega N A N E \theta H$ \\ ANTOHCETAITOY $I O C C$ TO \\ IOCAAEIAN $\triangle$ POYSI )MATV
}

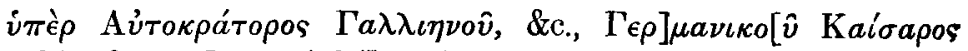

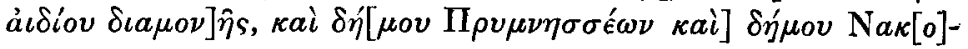

1 De Thematibus, i. pp. 14 and 25 ; the correct inference as to the general, though not as to the specirl, site of
Meros has already been drawn by several authorities, e.g. Kiepert on Franz, Fünf Inschr. 


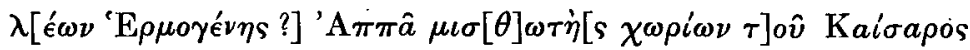

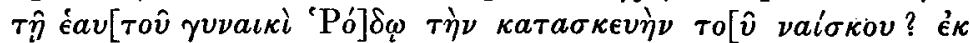

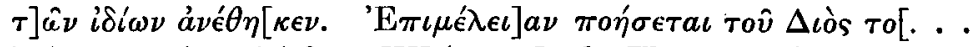

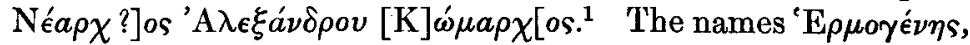

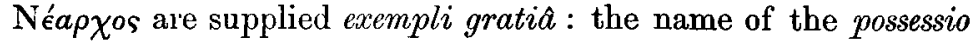
of the emperor may have been given instead of the suggested $\chi \omega \rho i \omega \nu$. I believe the restoration $\Pi \rho \nu \mu \nu \eta \sigma \sigma \epsilon \epsilon \nu$, though distant from Meros, is right. This monument was a tomb in the form of a (small temple?) of Zeus (See $J . H$. S., 1884, "Sepulch. Customs").

There is every probability that (Hermogenes?) was lessee of the saltus mentioned above as Kleros Oreines. The dominion of Prymnessos probably extended over Konna and Metropolis, so that Prymnessos and Nakoleia were neighbours of Meros and Kleros Oreines.

LXVII.-NAKolEIA was at Seidi Ghazi, as was first proved by the late Dr. Mordtmann. J. R. Steuart copied the inscriptions which prove this, and states that they do so, but as he did not print his inscriptions, his statement passed unheeded, and the false idea that Prymnessos was at Seidi Ghazi was universally accepted till Mordtmann's paper was published. Mordtmann however makes an error in concluding that Acroenos was a late name for Nakoleia. He does so because there is a great tekke 2 and the tomb of Seidi Ghazi here, and it is known that the historical Seidi Batal Ghazi was slain at Akroenos. But it is impossible to suppose that the Turkish dervishes who founded this tekke had any knowledge of an obscure historical fact of A.D. $739 .{ }^{3}$ Seidi Ghazi was one of the heroes of the Bektash dervishes-a sect which was once immensely powerful in Turkey because the Janissaries belonged to it, but which lost power when the Janissaries were exterminated by Sultan Mahmud. How he became their hero is unknown to me, but the connection between Nakoleia and Seidi Ghazi arises through the dervish tekke, and not from his death having occurred there. Seidi Ghazi is widely

$1[K] \omega \mu \alpha \dot{\rho} \chi[\eta s$ is also possible: the other letters, though incomplete, are certain.

2 Tekke, establishment of dervishes.

3 In Sultan Ala-Eddin's time the place where Seid died was discovered by a special revelation : a field near was called Shesh-enkutsch. The revelation was, as we now see, false : and no continuous tradition existed. For the story see Ethe, Fahrten des Sayyid Batthal, Leipzig, 1871, p. 215. 
known as a hero in Asia Minor, and a curious romance of his life exists in Turkish, and is accessible in a German trauslation : Akroenos was situated at Afiom Kara Hissar. Not. X. clearly distinguishes Nakoleia and Akroenos, giving the former as an archbishopric, the latter as a bishopric.

Nakoleia increased in importance during the Byzantine period, and was at some time after 787 dissociated from the metropolis of Synnada, and made an independent metropolis. ${ }^{1}$ In the year 862 Achillas was appointed archbishop of Nakoleia (Acta Sanctorum, Feb. 4, p. 549), but in Not. I., dated A.D. 883, the list of Salutaris is still uncorrected, and Nakoleia is ranked under Synnada, whereas in the latest Notitiae (II., III., X., XI., XII., XIII.) it is an independent metropolis, thongh apparently without any subordinate bishoprics.

Nakoleia shared in the usual Phrygian reputation for heresy. Theodotus, the Iconoclast Patriarch of Constantinople, was a native of Nakoleia. Constantine, also an Iconoclast, was bishop of Nakoleia during his time. ${ }^{2}$

Nakoleia possessed under the Roman Empire a wide territory, extending on the east up to the river Sangarios. The Byzantine system was opposed to such wide-spread power, and the history of Nakoleia shows a steady diminution in territory. This diminution also is coincident with a steady growth in prosperity and importance of the northern parts of Phrygia, which may be clearly traced in Byzantine history. Southern Phrygia was far more important under the Roman Empire, lying as it did on the great eastern highway; but northern Phrygia grew steadily when roads led to Constantinople. The great Byzantine military road ${ }^{3}$ went by Dorylaion and across northern Phrygia. I cannot here do more than briefly indicate the line of this road. It was first regularly organized by Justinian, who formed a series of fortres:es

1 In the earlier Notitiac the interme-

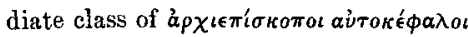
exists, but these archbishopries are all converted into metropoleis in the latest Notitiuse.

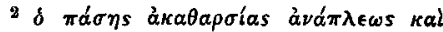

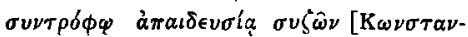

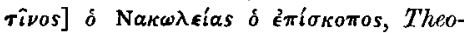
phan. I. 402.

ó $\psi \in v \delta \leftarrow \pi i ́ \sigma \kappa o \pi o s ~ N a k o \lambda i ́ a s$ kal oi $k \alpha \tau^{\prime}$

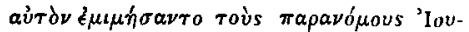

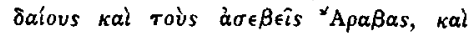

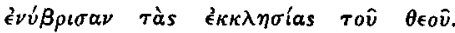
Theophan. contin., 484.

${ }^{3}$ It has to be distinguished from the direct road to Ankyra, the pilgrim's route, which I have describerl in an Appendix to the translation of the Bordeaux Itinerary published by the Palestine Exploration Fund. 
along it-Justinianopolis Mela, Dorylaion, Justinianopolis Palias (Sivri Hissar), \&c. A series of ă $\pi \lambda \eta \kappa \tau a$, points where the armies of the different provinces assembled to join in any eastern campaign, were formed along the road-at Malagina, Dorylaion, Kaborkion, Colonia (Archelais), Caesareia (Mazaka), and Dazimon. ${ }^{1}$

The following villages of the territory of Nakoleia are known : some of them afterwards became independent bishoprics :-

LXVIII.-KAKKABAS, or KAKKABOKOME, was a village in the territory of Nakoleia, known from an inscription found at Khozrev Pasha Khan (where I copied it in 1881 and 1883):

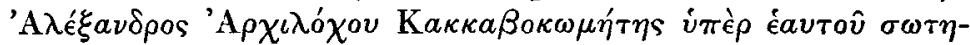

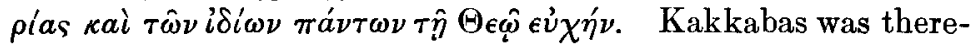
fore probably the small ancient town situated at Bassara, about a mile to the east of Khozrev Pasha Khan. The village is mentioned in the fifth century, when at the Council of Ephesus, in

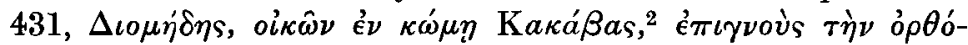

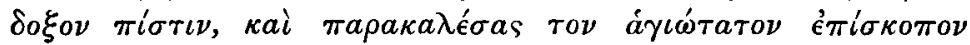

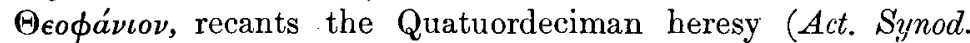
Ephes, Mansi, IV., p. 1361).

LXIX.-SANTABARIS is mentioned on the route of the Emperor Alexius Comnenus, between Dorylaion and Kedrea (now Bayat), and may therefore be identified confidently with the modern village Bardakchi, where there are numerous Byzantine remains. The account of Theodorus Santabarenus (Vit. Nicolai in Act. Sanct., Feb. 4) also suggests that it was near Nakoleia.

LXX.-Petara is known only from a dedication $\Delta i i \Pi e \tau a-$ pai $\boldsymbol{\omega}$, copied at Baghlije, in 1883 (Sterrett-Ramsay) :-

\section{CWKPATHCNEIKO^AOY EPMHC KAI $T A I O C$ MHNO ФIHOY NAKOAEYC $\triangle I I \Pi \epsilon$ TAPAIWEYXHN}

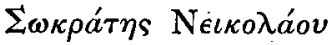

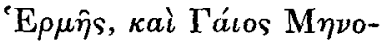 \\ $\phi i \lambda o v \mathrm{Na \kappa} \kappa \lambda \epsilon \dot{s}, \Delta \iota \grave{i} \Pi \epsilon-$

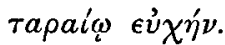

This dedication by Gaios and Socrates Hermes leaves it doubtful whether Petara is actually part of the territory of Nakoleia or belongs to Amorion.

\footnotetext{
1 Malagina is apparently a late name for Justinianopolis Mela, now Bilejik : Colonia Archelais is now Ak Serai : Dazimon is the Faz Ova north of Tocat :
}

on Kaborkion see below.

2 The Latin text has in vico Caccaba or Choccaba. 
LXXI.-Serea. LXXII.-VEkrokome. (See J.H.S., 1884, pp. $258-260)$.

LXXIII.-A surname of the native god of Nakoleia, probably derived from a place of his worship, occurs in the following inscription on a defaced stele at Seidi Ghazi (Ramsay, 1881; Sterrett-Ramsay, 1883). ${ }^{1}$

\section{KOPNHAIOC ANTWNIOC$$
\triangle I I \text { PYMIW }
$$ EYXHN}

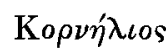

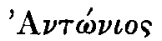

$\Delta \iota \grave{ }{ }^{'} \mathrm{P} v \mu i \omega$

$\epsilon \dot{v} \chi \eta^{\prime} \nu$.

LXXIV.-KABORKION ${ }^{2}$ was an $a^{\prime \prime} \pi \eta \eta \kappa \tau o \nu$, where the troops of the Anatolic Theme collected, and must therefore have been in a good camping position near the Byzantine military road which ran between Dorylaion and Justinianopolis Palias (Sivri Hissar). The one fine position in this district is at the fountains of the Sangarios; and here to the present day there is at Tchifteler a station for cavalry and an estate of the Sultan.

The position of Kaborkion is given (1) by the description of the äm $\pi \eta \kappa \tau a$ in Constantine Porpbyr., De Cerimon. I., app., p. 444, and (2) by the fact that it was a bishopric of Salutaris. Now the discussion of the bishoprics of Galatia Salutaris will show that the country along the right bank of the Sangarios was inhabited by the Orkoi or Orkaorkoi, one of whose towns was called Orkistos; etymologically there must be a connection between the people Orkaorkoi and the town Kaborkion, which in earlier time would be spelt Kaovópкıо, and in later time

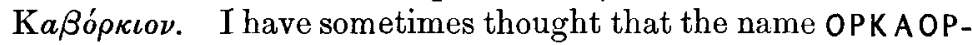
$\mathrm{KOI}$, known only from Strabo, is corrupted from KAOYOPKOI, and that Kaovópкion is the centre of the Kaov́opкou.

The territory of Orkistos and of Kaborkion originally was subject to Nakoleia. Orkistos was made independent 331 ; Kaborkion was in all probability made independent by Justinian when he formed the great military road, and though it does not appear in any Notitiae except III., X., XIII., we observe that precisely

1 Published by me incomplete, $J$. $\pi$. $S ., 1882$, p. 125 . The restoration proposed by Prof. Gomperz, Arch. Epigr . Mitth. Oesterr. vi. p. 52, is incorrect.
${ }^{2}$ In Not. X. and XIII. the name is given twice Kamarkos and Tabarkion: Not. III., which is a copy of the same list, gives the correct text. 
these three Notitiae alone preserve the name Justinianopolis, which was for a time given to Seiblia.1

LXXV.-SANGIA. Its situation is mentioned by Strabo, the only author who gives the name. It was at the fountains of the Sangarios, 150 stadia from Pessinus-decidedly an understatement. Sangia was therefore one of the villages of the Kaborkoi.

LXXVI.-PAZON, another village in the same neighbourhood, is twice mentioned by Socrates as a seat of the Novatians. The same remarks apply to it as to Sangia. It was included in Phrygia when we hear of it (about 400), which is natural, as it was in the territory subject to Nakoleia.

LXXVII._ORKISTOS was made independent in 331, and transferred between 386 and 395 to Galatia. It is impossible to gain a clear idea of the eastern border of Phrygia without discussing the western part of Galatia, the province which was called Galatia Secunda or Salutaris in Byzantine time. The whole of this district was originally Phrygia, and the boundary between the two provinces varied much at different times. Space prevents me from discussing the subject here, but I hope to prove elsewhere that Amorion, Klaneos, Orkistos, and Trikomia were taken from Phrygia by Theodosius 386-395, and used to form the new province of Galatia Secunda.

LXXVIII.-DorylaIon. Its position at Eski Sheher, with its hot springs, has long been known. Lying where the important roads from Constantinople to the east and to the south fork, it was a place of the first importance, and is connected with many events in Byzantine history.

It is mentioned at Concil. Chalcedon. 451, in such a way as to show that it was then av่roré $\phi a \lambda o s$, and not subject to the metropolitan of Synnada; but in all the Notitiae it is an ordinary bishopric. It was a station of Scholarii (as was Kotiaion) until Justinian's time (Theophan., p. 236).

The ruins of Kara Sheher, three or four miles W.S.W. of Eski Sheher, probably mark the city built by Manuel Comnenus in his attempt to strengthen the empire against the Seljuk power (A.D. 1175). Dorylaion had then been in ruins for some time, and the new city was built on a different site. The Roman city stood round the mound now called Sheher Eyuk, two miles

1 This I have proved in my forthcoming 'Antiquitics of Sonthern Plırygia.' 
north of Eski Sheher; the hot springs are at the northern outskirts of Eski Sheher.

The river Tembris, called Thyaris by Cinnamus, flows past Dorylaion, and receives a tributary called by the same historian Bathys. The Tembris in its upper course was called Tembrogius, as is recorded by Pliny and corroborated by an inscription which I copied in the district Praipenissos, at Utch Eyuk, in 1884 .

LXXIX.-MeZEA was a village in the territory of Dorylaion, mentioned in the following two inscriptions copied by me in 18̣83, at Eski Sheher :-

(1) On a stele, under a relief of bull's head; broken at bottom :

\section{MLZCAN \\ WIIIHPAKAH \\ NEIKHT $\Omega$ \\ AN $\Omega \cdot$ K EK}

$$
\begin{aligned}
& \mathbf{M}[\epsilon] \zeta[\epsilon] a \nu- \\
& \text { o] } i \text { 'Н } \rho a \kappa \lambda \hat{\eta}
\end{aligned}
$$

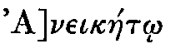

$$
\begin{aligned}
& M \epsilon \zeta] a \nu \hat{\omega} \kappa \hat{\epsilon} \epsilon \kappa
\end{aligned}
$$

\begin{tabular}{|c|c|}
\hline XOIKAI & ... $\chi^{o \iota} \kappa a i$ \\
\hline MEZEANOIMH & $\mathbf{M} \epsilon \zeta \in a \nu o i \mathrm{M} \eta-$ \\
\hline TPIEYXHN & $\tau \rho \grave{i} \epsilon \dot{v} \chi \eta^{\prime} \nu$ \\
\hline
\end{tabular}

(2) On lower part of broken stele :

LXXX.-Midaion. Its position is determined (1) by its situation on the Tembris, which is mentioned on its coins; (2) by its distance-eighteen miles from Dorylaion, on the road to Tricomia and Pessinus. These conditions point to Karadja Euren, where important remains reveal the site.

LXXXI.-Krassos. This plain, mentioned once or twice in the Byzantine wars, was situated, as I have proved in Appendix I. to Part I., on the lower Tembris.

LXXXII_-GoRDORINIA, or GoRDorounIa, is mentioned only in Not. III., X., where it occurs with Kaborkion at the end of the list. I have already shown that the north-eastern corner of Salutaris increased in importance during the fifth and sixth centuries, and that these bishoprics at the end of Not. III., X. perhaps preserve to us the state of the province soon after the reorganization by Justinian. Hence this bishopric may be safely 
placed in the north-eastern district of Phrygia. Now there remains little room except between the river Tembris and the middle course of the Sangarios, or on the Tembris below Midaion in the plain of Krassos, and no name has ever yet been placed in this utterly unknown plain. Another argument may be derived from the name, which is probably equivalent to "the Orounia of the country Gordos"; we have then to inquire about this country, Gordos, whose very name has hitherto escaped notice.

LXXXIII.-Gondos, as a district of Phrygia, is mentioned in a few rare cases. In the life of Theodore Sykeota, ${ }^{1}$ we find that in Buzacorum loco, sub Gratianopolim sito, in the regio Gordiana and beyond the boundaries of the province Galatia, the people were making a bridge over a stream liable to be swollen by torrents. The very name Gratianopolis is unknown except in this passage; but the story shows that the place was not very far from Sykea, and on the south side (out of Galatia Prima). Again the town Justinianopolis Mela in Bithynia is often called Justinianopolis Gordi at the Council of 553, i.e. Justinianopolis of the country Gordos: the old name Juliopolis (west of Sykea twenty-four miles) was $\Gamma o ́ \rho \delta o v ~ K \omega ́ \mu \eta$, where also I understand the country Gordos: Gordorounia, which appears to be in the same country, and Gordoserba, which lies near Bilejik, probably contain the same name. These scanty traces point to a country Gordos extending from Bilejik eastward between the Sangarios and the Tembris. The mythical Gordos, father of the Phrygian historical king Midas, is probably the eponymous hero of this country.

The life of Theodore Sykenta contains some information about this obscure country, A.D. 550-600. There was a direct road from Lagania (Anastasiopolis) to Dorylaion (p. 58), by which Theodore went to Constantinople instead of taking the short road by Juliopolis and Tataion. The bad text and the utter want of exploration make it impossible at present to fit on the story to the country; only the conjecture may be made after the preceding remarks that Gratianopolis is perhaps Gordorounia, and if so, we have a proof of the period when this country began to come into importance. 
LXXXIV.-Kotiaion still retains the old name as Kutaya, and is one of the great cities of the interior. I adopt the spelling favoured by coins, but Kotvaiiov is a common form, and the connection with the Phrygo-Thracian Kótus cannot be doubted. There is no doubt that Kotiaion was ranked in Salutaris, not in Pacatiana; numerous testimonies confirm Not. VIII., IX., which mention it first among the bishoprics subject to Synnada. We saw that Dorylaion aimed at independent rank in the fifth century: we have no express proof that Kotiaion also did so, but it can hardly be doubted that it would not be less attentive to its dignity than the smaller town of Dorylaion. I believe that it maintained its right to be autokephalos in the fifth and sixth centuries, and that this is the reason of its omission from Hierocles' list. We have a parallel case in Eukhaita of Pontus. It is omitted by Hierocles, and it is known to have been autokephalos at an early time: it is mentioned by the Notitiae as an archbishopric, and not as an ordinary bishopric subject to Amaseia. In both cases Hierocles, who is much influenced by the ecclesiastical lists, has been misled. ${ }^{1}$

But it is clear that in 692 and 787 Kotiaion had not the position of autokephalos: it ranks among the ordinary bishops of Salutaris. So Dorylaion appears as of higher rank in 451, and as an ordinary bishop of Pacatiana in 553.

Kotiaion grew steadily in importance during the Byzantine period, and is placed by Const. Porphyr. second only to Nicaea in the Opsikian Theme, Dorylaion being third, and Midaion fourth. The list proves the importance of northern Phrygia in later time (see LXVII.). It ranks as a metropolis in Not. I., III., X., XIII. In Not. III. and X. three bishoprics of Salutaris are placed under its authority-those which lie on the important road to the south and east, passing from Constantinople, by Kotiaion and Akronios: this road is often mentioned, and was used as an alternative route to the Dorylaion road by the Byzantine emperors in going from Constantinople to the East. $^{2}$

1 At the same time, pending further investigation, I quite admit that Eudokias (as I was disposed some years ago to think) may be a temporary name of
Fotiaion, and that for some reason or from error Hicrocles may have placed it in Pacatiana.

${ }^{2}$ See Ambason. 


\begin{tabular}{|c|c|}
\hline Not. IIJ. & Not. $\mathrm{x}$. \\
\hline 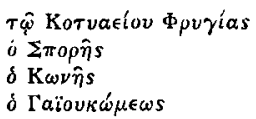 & 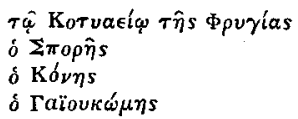 \\
\hline
\end{tabular}

Of these three subordinate bishoprics Kone has already been discussed and placed. The other two bishoprics must be placed on the roads (one now in use as a waggon road, the other as a horse road) which connect Kone with its metropolis, Kotiaion (see XCI., XCII.).

At the end of his list Hierocles gives four demoi. ${ }^{1}$ These seem to be classed together, not because they were near each other geographically, but because they are demoi, as distinguished from the preceding poleis.

LXXXV.-Demos Lykaonon. The Lycaones are a people rarely mentioned, and it is therefore difficult to localize them. Besides the Byzantine lists, Pliny and Ptolemy mention them. Pliny (v. 105) gives the Lycaones in the conventus of Synnada. Ptolemy mentions them in a passage which requires correction : I

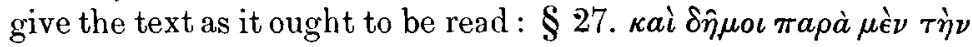

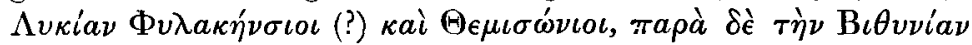

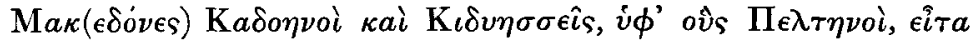

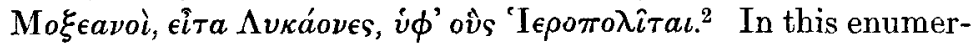
ation Ptolemy arranges the demoi in lines from east to west:

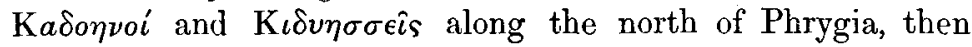
along a line further to the south Peltenoi, Moxeanoi, and Lykaones; south of the Lykaones lie the Hieropolitai. These

J Hierocles mentions them in the genitive, because he uses as authority lists of bishoprics.

* In this passage 1 have transposed

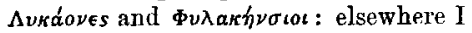
have proved that this change introduces geographical accuracy, in place of inconceivable inaccuracy. The error was produced by a would-be corrector, who thought that $\Lambda v \kappa a ́ o v \in s$ must be $\pi a \rho \alpha े$

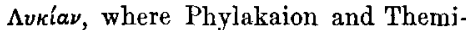
somion were adjoining cities on the Lycio-Caro-Phrygian frontier (see my paper on 'Antiquities of Southern Phrygia,' in the Amer. J.Arch. 1887). I have also corrected the form of $K v \delta\llcorner\sigma$ -

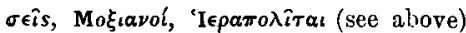

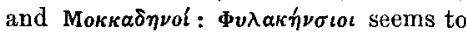
ine a false form (perhaps $\Phi$

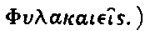


lines are approximately correct, if we understand that the Peltenoi include the population of the entire plain of Ishekli,

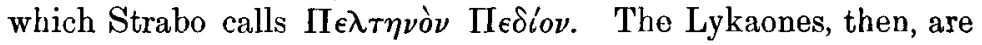
the people of the Cutchuk Sitchanli Ova, which lies north of the Sandykli Ova; and this is one of the districts that we have hitherto left vacant in placing the names given by Hierocles.

The preceding passage of Ptolemy seems to me conclusive, unless we suppose that Ptolemy has attained in this description a degree of inaccuracy which he does not elsewhere succeed in reaching. ${ }^{1}$ But I discovered the site from other reasons or presumptions, and after discovering it I observed the correction required in Ptolemy. My first reasoning was from the frequent references in Byzantine documents to a monastery of the Lykaones; now among the hills which separate Lykaones and Prymnesseis there is still a monastery of considerable fame and sanctity, ${ }^{2}$ and in a country which has been almost wholly Turkish for centuries such a monastery must be an old establishment.

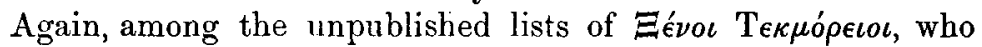
formed a religious union worshipping Artemis of the Limnai, a

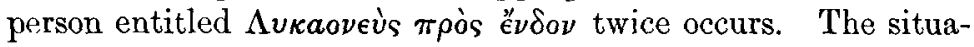
tion assigned to the Lykaones fills up the circle of districts round the Limnai, and this consideration, combined with the passage of Pliny and the fact that the Lykaones were a Phrygian people, constituted sufficient evidence of the situation, and gave me the clue to understand and correct Ptolemy.

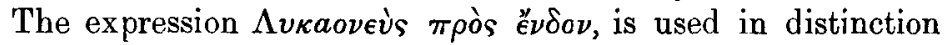
from the Lycaonians proper, whose country is nearer the southern sea.

The monasteries of the Lycaones are frequently mentioned in Concil. Constantinop. A.D. 536. The following are the chief references:-

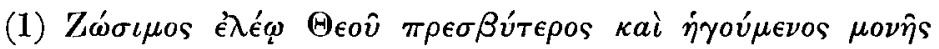

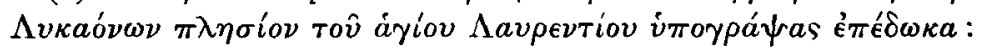
Labbe, p. 133.

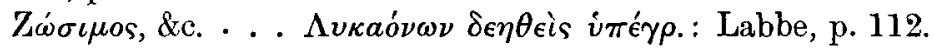

1 Except in the Strategiai of Cappadocia, but the geography of that country is very ditficult even with modern maps, and was then little known, whereas this part of Phrygia was well known.
2 Near Kalejik: I have not visited it. The permanence of religious institutions in Asia Ninor is an interesting subject in many respects. 
Z⿳́㇒兀

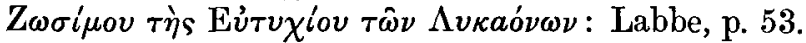

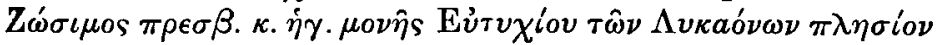

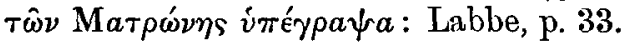

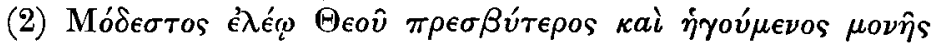
$\tau \hat{\omega} \nu \Lambda$

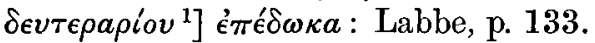

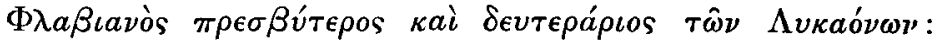
ib. p. 76 .

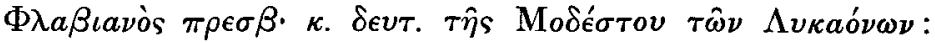
ib. p. 53.

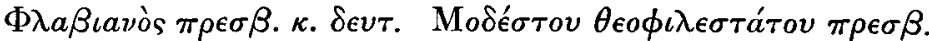

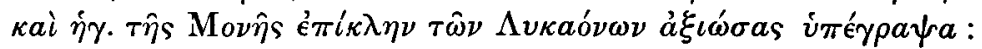
ib. p. 33.

The doubt is whether these monasteries are actually in the city of Constantinople, or merely subject to Constantinople; the formor is the natural interpretation of the text, but seems impossible.

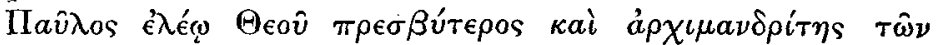
$\Lambda$ perhaps due to some mistake.

No bishop of the Lycaones was present at any Council.

LXXXVI.-Aulokra, Aurokra, Aurokla, is mentioned by Hierocles in the form $\delta \eta^{\prime} \mu a u$ Aúpák $\lambda_{\epsilon \iota a}$, which is either a false form or a corruption. The situation of this demos is fixed by the fountain and lake Aulokrene, which lie on a plateau behind Apameia to the east, and according to the unanimous belief of ancient and modern time supply the great fountains of the Maeander and Marsyas in the lower valley. I have little to add to the description of the fountain and its surroundings which I have given in my paper, "Metropolitanus Campus" (J. H. S., 1883); the argument by which it was there shown that the fountain Aulokrene was the same which is mentioned by Livy on the march of Manlius, is confirmed by the observation which I subsequently made that the Rhotrinos Fontes in Livy (altered in almost all the editions, quite unjustifiably, to Obrimae Fontes) is only a slight corruption of Rhocrinos, the adjective derived from $[\mathrm{Au}] \mathrm{rocra}$. The name Aulocrene must have been originally

${ }^{1}$ Restored from the Latin version, and from the other signatures.

H.S.- VOI. VIII.

I. I. 


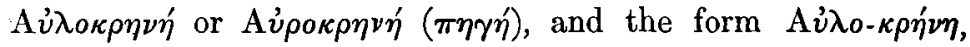
"flute-fountain," is a typical example of the influence exerted on Anatolian nomenclature by popular etymology seeking to give Greek meaning to non-Greek words. This name, combined with the importance of the flute in Phrygian music, ${ }^{1}$ gave form to the Greek legend of Apollo, Marsyas, and Athena.

LXXXVII.-METRopolis. In my older papers I have distinguished correctly between the two Phrygian Metropoleis, and have shown that all coins which read MHTPOחOAEIT $\Omega N$ QPY must be referred to the Metropolis situated in the Tchul Ova, south of Synnada. This city was in the Byzantine province of Pisidia. In the Byzantine provincial division it is hard to understand why Apameia and Metropolis were assigned to Pisidia, while Aurocra, which lies on the road between them, was assigned to Phrygia Salutaris. The reason may lie in the history of Aurocra. There can be no doubt that in the great days of the prosperity of Apameia, the valley of Aurocra was part of its dominion; in later time, when Apameia ceased to be one of the great cities, ${ }^{2}$ Aurocra became independent, and acquired the rights of a $\pi{ }^{\prime} \lambda \iota s$ in accordance with the common Byzantine policy. To emphasize the separation, and completely destroy all sense of dependence, Aulocra was placed in a different province.

LXXXVIII.-Praipenissos, Propniasa. The latter form is probably corrupt, while the former, which occurs in Ptolemy ${ }^{3}$ and at Concil. Chalcedon., is a Grecised form. The variation of forms in $-\sigma \sigma o ́ s$ and $-\sigma a$ is common in the Greek representation of Anatolian names. The true native form probably lies between Hierocles and Ptolemy.

Praipenissos is placed by the following considerations: (1) it is within the bounds of Phrygia Salutaris; (2) it is given by Ptolemy as a midland city of Mysia. Only a city in the north-

1 One who listens to the remarkable music of the flute and crmbals at the dances of dervishes in Konia or Kara Hissar of Phrygia can understand the intoxicating influence which it had over the devotees and populace of antiquity.

2 This must be subsequent to the founding of Constantinople : the road system was then revolutionized: all roads henceforward led not to Rome but to Constantinople, and Apameia, previously on the great eastern highway, was on a mere by-road, away from the main tracks of intercourse. Not. X., XIII. confuse Abrokra and Kaborkion.

3 Prepenissos in Mysia interior with Alondda and Trajanopolis. 
western part of Salutaris fulfils these conditions, and only the Altyntash district remains unoccupied. Now it was shown above (LXXXV.) that Ptolemy conceives the Kidyesseis and the

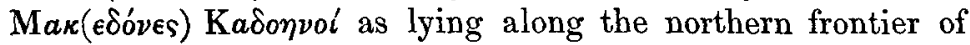
Phrygia towards Bithynia, and Propniasa, which lies further north, cannot be reckoned by him as part of Phrygia; on the other hand, his language in the passage there quoted would suggest that Praipenissos should be assigned to Bithynia. If he assigns it to Mysia, and if, again, he places Kotiaion and Dorylaion in Phrygia, these, like many similar contradictions in his work, are to be attributed to his use of different authorities. The boundaries of Phrygia and Mysia were so uncertain as to be

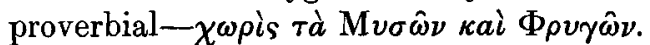

The authority of Ptolemy may also serve to prove that Praipenissos lay south of Dorylaion and Kotiaion; if it had lain to the north of these towns, it would have been in the Roman province Bithynia-Pontus, and there would then have been much less danger of misplacing it. Ptolemy's lists are very fairly accurate as regards the Roman lines of division, where he had definite authority to trust to, but they are very loose as regards the historical and non-existent lines of division within the Roman provinces, in which his authorities contradicted each other in the most puzzling way.

LXXXIX.-BENNISOENOI are proved by published inscriptions to have been a demos inhabiting the plains around Altyntash. The Bennisoenoi, not being mentioned in any Byzantine list, must have been included in a bishopric which bears another name, and the evidence has already forced us to place Prepenissos in this region.

In the following remarks $I$ expose myself to the charge of overstraining the possibilities of language, but I think that a full statement of the actual corruption of native Anatolian names in giving them a Greek dress and appearance (which cannot be made here) would justify me. I believe that the second part of Pre-penissos is a Grecised form of Bennisoa. There was a great tendency to the termination $-\sigma \sigma o s$, which is a Grecism of an Anatolian -s or $-\sigma a$; and I look on Pre- as a prefix. I compare the wile variety of forms given to the name of the city which struck coins with the legend $T P \in B \in N N A T \curvearrowleft O N$, Prebena, Trebena, Trebenna, Perbaina, and Trebendai (Ptolemy). The Gallic, 
Messapian, and Thraco-Illyrian word Benna (Deecke, Rh. Mus. 37, p. 385) means 'waggon': Bennis-oa, 'having treasure of waggons' (Steph. Byz., s.v. Souagela): Zeus Bennios or Benneus (like Jupiter Stator according to Benfey), 'he who stands on a car.' 1

XC.-Skordapia. We have still to compare the evidence of the Notitiae. The district where the Praipenissos of earlier time (Ptolemy, Hierocles, and Concil. Chalced.) was situated, must have been a bishopric still in late time. In Notitice VII., VIII., IX., I., there remains only Skordapia, or Skordaspia, to be placed, and the unsatisfactory method of applying the one remaining name to the one remaining district is our only resort. In Notitiae III., X. XIII., we find no Skordapia, but instead of it we find two bishoprics, Spore and Gaiou Kome, which are definitely proved to belong to this district. Now, Skordapia is a suspicious form, and we shall see that a name Sgerca was perhaps equivalent to Spore, while it is known that Apia lay on the west of this district. These slight presumptions lead me to see in Skordapia a corruption of the name of one or other of the two bishoprics into which the rich and fertile district of Praipenissos was cut in the ninth century; these two bishoprics must be discussed next.

XCI.-Spore is mentioned in Notitiae III., X., as subject to the metropolis Kotiaion. The reasons already given place it between Kotiaion and Konni, and an inscription, brought from Karagatch Euren to Kotiaion (J.H.S., 1884, p. 259), perhaps mentions the same place under the name Isgerea. I should, in accordance with these slight indications place this bishopric in the plain between Doghan Arslan and Gerriz.

Isgerea was a village of the country which worshipped the god Benni (J. H. S., 1884), and in the growing importance of this district it became at last a bishopric. The ruins of late date, but of considerable extent, near Gerriz satisfy all these conditions, and demand a name corresponding to their importance.

XCII-GaIOU KomE is the third bishopric under Kotiaion, which remains to be placed between Kone and the metropolis. The important site of Altyntash ('Stone of Gold') on the horse-

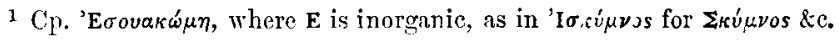


road remains without a name, and the remains show it to have been a place of real importance in late Roman and Byzantine time. Probably Гaiov $\kappa \dot{\omega} \mu \eta$ is the Christian name of the village, whose church was dedicated to a saint Gaius; otherwise such a name is unintelligible, and must be considered as a corruption. An inscription in very worn letters which I copied there in 1881 and 1884, mentions 'ATOYK $\Omega$ MHL; I have sometimes thought that the true name has to be found between Gaiou and ATOY.

XCIII.-TotroIA, the ancient name of the village Besh Karish Eyuk, is proved by the following inscription, in a cemetery one mile and a half north of the village, copied by me in 1884:

$\begin{array}{ll}\text { OPOITO } & \ddot{o \rho o \iota ~ T o-~} \\ \text { TTOH } & \tau \tau o \eta- \\ \text { NWN } & \nu \hat{\omega} \nu .\end{array}$

The name occurs also in Bithynia in the forms Tátaıov, Tazaoú-

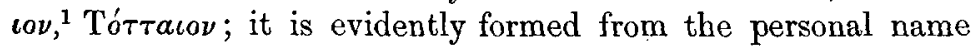
Tatas or Tottes, the stem of which must be Taraf or Tarv, from which comes Taraf-ıo- $\nu$.

XCIV.-Tribanta is mentioned only by Ptolemy, whose indications point to a position a little west of Azanoi. It may occur in the following inscription, though there is no evidence of the restoration; I copied the inscription at Zemme in 1884. The stone measured fourteen inches in breadth, of which eigbt inches on the left are broken away:

\begin{tabular}{|c|c|}
\hline NT $\Omega$ NOLI $\Omega$ & 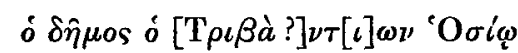 \\
\hline KO $\Omega E Y \mp A M E$ & 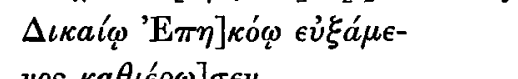 \\
\hline
\end{tabular}

XCV. - ABEIKTA occurs only in the following inscription (copied by me at Yaliniz Serai in 1885), which proves that it was one of three neighbouring villages united in a union or Trikomia :

1 So Ptolemy's חaraov́ıv must be corrected. 
MHNACMHNA $\triangle O C$

ABEIKTHNOCYTE

PTHCTPIKWMI

ACCWTHPIACKA

ITWNI $\triangle$ I WNTAN

TWNANEOHKEN

$\triangle E I B E N N I \omega E Y$

$X H N$

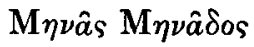

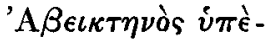

$\rho \tau \hat{\eta} s \mathrm{~T} \rho \iota \kappa \omega \mu i-$

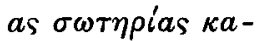

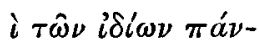

$\tau \omega \nu$ à $\nu \in \hat{\theta} \theta \kappa \epsilon \nu$

$\Delta \epsilon i \mathrm{~B} \in \nu \nu i \omega \in \epsilon \dot{v}-$

$\chi \dot{\eta} \nu$.

Abeikta, [Triba]nta, and a third village at Utch Eyuk, were perhaps the Tricomia.

The Latin dedication at Yaliniz Serai to an Augusti dispensator suggests the possibility that some imperial property existed here, and its boundary may be marked by another Latin inscription of the district (Eph. Epigr., No. 1451).

XCVI.ZZingot. XCVII_-Iskome. (J. H.S., 1884, p. 261.) The name Zingot recalls a Scythian type, Skolot, \&c., on which see Neumann, Hellenen in S7ythenlande, p. 179. All these places (XC. to XCVII.) belong to the district Praipenissos.

After this discussion of Salutaris there remains now little to detain us in north-western Phrygia.

XCVIII.-APPIA. The name of Appia is still retained under the form Abia to designate a small village, where a Roman bridge and numerous remains reveal the ancient site. The territory of the city includes the country along the northeastern side of Mount Dindymos (Murad Dagh), in which a very large number of villages exist, never yet visited by any traveller. With this name Appia the Phrygian personal names Appios, Appia, Appion, \&c., are probably all connected, and all are derived from Appa, or Appas, a name of the god understood as the father: cp. Papas of Phrygia and Bithynia.

Appia was a station on the Roman road between Kotiaion and Akmonia. This road is defective in the Peutinger Table, and should probably be read as follows: Dorylaeum, Cotiaenm, Appia, Akmonia, Aludda, Clannudda, Philadelphia.

The course of the road is marked by the following milestones :

(1) The eleventh milestone from Akmonia (see XXII.).

(2) The sixth or seventh milestone north of Appia ȧiò 
Ammias $\mathrm{M} i(\lambda \iota a)$ s or $\zeta(C . I . G .3857 e$, Lebas-Wadd. 788), found at Geukcheler.

(3) The eighth milestone north of Appia, a few fragments at the end of lines, and at the foot the distance $\mathrm{MH}$, copied by me in 1884 at Geukcheler. This may be the same inscription as Lebas-Wadd., 787, C. I. G., 3857d, where the number is lost.

(4) The twelfth or thirteenth milestone from Appia was copied by me at Haidarlar in 1884; it gives the line of road between Appia and Kotiaion, which evidently follows the gorge of the Tembris, or Tembrogius ${ }^{1}$ :-

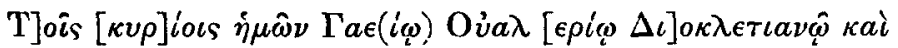

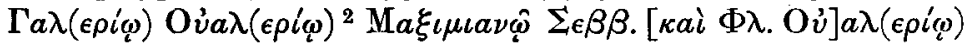

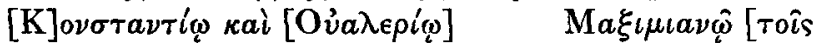

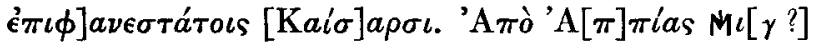

XCIX.-Eudokias is mentioned only by Hierocles, who places it between Apia and Aizani ; this points to a situation on the north side of the Murad Dagh (M. Dindymos) in a country absolutely unknown, but which has been reported to me to contain many villages (see also KotiaIoN, footnote).

C.--In the latest Notitiae, III., X., XIII, five bishoprics, Aizanoi, Tiberiopolis, Kadoi, Ankyra, and Synaos, are disjoined from Laodikeia and placed under Hierapolis. The five form a group in the north-west corner of the province. The reason and the exact period of this change are unknown, but it had taken place before Concil. Nicaen. II., A.D. $787,{ }^{3}$ while it had not come into operation in the Councils 680 and 692 . The other Notitiae take no notice of this arrangement, but mention all these bishoprics as subject to Laodikeia.

We have therefore here a clear proof that Notitiae VII., VIII., IX., and I., give an arrangement of Pacatiana which had already become antiquated in 787 , although $\mathrm{I}$. is dated 883 , and the others all contain some traces of early ninth century institutions.

CI.-AIzanoI. The site at Tchavdir Hissar, with the striking ruins of the temple of. the native god, who was identified with the Greek Zeus, has long been known.

1 The course of this river is utterly

false in Kiepert's map. $\quad 2$ sic.

3 The evidence of Concil. Constantin.
870 is doubtful, but rather tends to show that the original arrangement had been restored. 
CII.--Tiberiopolis is very rarely mentioned, and topographical evidence is wanting. The order of Hierocles demands a situation in the north of Phrygia, which is opposed to the far inferior authority of Ptolemy. Notitiae I., VIII., IX., also mention it with Aizanoi, Ankyra, and Synaos, and the authority of the arrangement in III., X., XIII., confirms this position. I see only two possibilities: either Tiberiopolis is to be placed where I have placed Eudokias, and Eudokias is to be identified with Kotiaion-a supposition which has been already rejected; or Tiberiopolis was the city whose remains exist about Amet, Hassanlar, and Egri Göz. M. Waddington (Lebas-Wadd., 1011) places Ankyra there, but the inscription on which he relies, reading 'A $] \nu[\kappa v \rho a] \nu \hat{\omega} \nu$, does not justify the restoration, as may be seen by comparing the epigraphic text. Ankyra was certainly not situated here (see CIII.). The published inscrip-

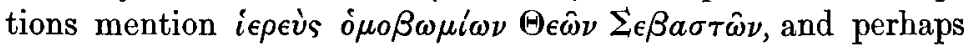
ié $\rho \epsilon \iota a \nu \nu \epsilon \hat{\omega} \nu$ [ó $\mu о \beta \omega \mu i \omega \nu]$, and another which I copied in 1884 at Amet on a basis reads :

\section{TEKNAחATPI KAIQEOTIMHN}

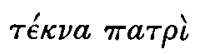

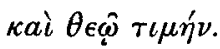

These inscriptions prove that a cultus of the early emperors was a prominent feature in the city. M. Waddington interprets the

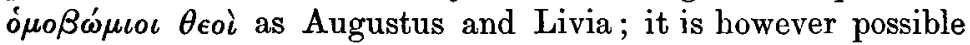
that Tiberius and Livia are meant, or that Tiberius gave the city leave to adopt his name and institute a special worship of his parents.

The inscriptions of this valley prove that a city of early imperial civilization existed here. If it is not Tiberiopolis, it must be some city of Mysia, and I find none which could well be placed here. On these grounds I place Tiberiopolis at the head waters of the Amed Su, a tributary of the Rhyndakos. Its course is falsely given on Kiepert's map; I was assured by natives that it joins the Rhyndakos near Harmanjik.

CIII.-AnkyRa. CIV.-Synaos. These two cities, whose names are in some Byzantine authorities given as a single word Ancyro-synaos, have been proved by Hamilton at Simav and Kilisse Keni. I have visited both places, and have nothing to add to Hamilton. I have already referred to M. Waddington's 
theory that Ankyra was situated at Hassanlar (see CII.). Ankyra bears the title Ferrea or Sidera in some Byzantine lists.

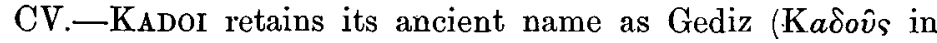
accus. $\left.{ }^{1}\right)$. It is on the upper waters of the Hermus, which is on

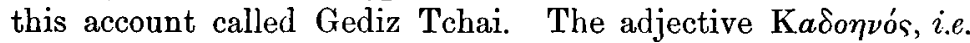

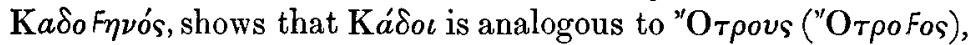

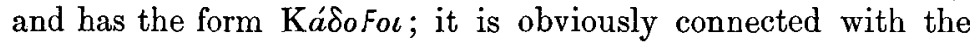

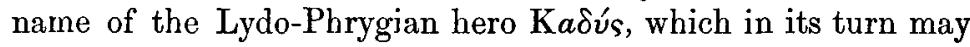
perhaps be a variety of the Phrygo-Thracian Kotús. ${ }^{2}$

CVI.-Theodosia is called THEodosioupolis in Concil. Chalcedon. If we may judge from its position in Hierocles between Kadoi and Ankyra, it was situated at the important mining centre Shap Khane, 'Alum House,' which is still the seat of a mudir. The original name of this place is unknown; the name Theodosiopolis, given to it doubtless when it was dignified with the rank of a $\pi o^{\prime} \lambda_{\iota}$, soon passed out of use again.

CVII.-TemenothyraI. The situation is determined by the situation (1) outside of the bounds of Lydia, (2) on the river Hyllos. ${ }^{3}$ The Hyllos is known from coins to be the tributary of the Hermus that flows past the Lydian Saittae, and only its upper waters can lie across the frontier and within Phrygia. The name clearly means 'the Gates, or Passes, of M. Temnos,' and the allusions to this mountain suit and almost necessitate its identification with the great chain that extends east and west on the southern side of the valley in which lie Synaos, Ankyra, and the river Makestos. Of the many villages which doubtless existed in the territory of the Temenothyreis, we know the name only of one, Koloe (see CX.).

CVIII.-TRAJANOPOLIS has been proved by M.Waddington to be a name given to the central town of the people Grimenothyreis. It corresponds to the important modern city Ushak, but the view of $\mathbf{M}$. Waddington that it was situated there is not strictly accurate. The actual site was at Giaour Euren, six miles east of Ushak, near Orta Keui; the rock-tombs near the site have been described by Texier. The actual date of the foundation is perhaps given in the following inscription in the outer wall of the mosque at Tcharik Keui; it was copied first

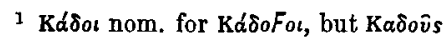

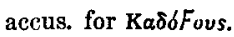

2 The variation of vowel as in Atreus and Otreus, Attalos and Ottalos, Tataion and Tottaion.

3 Pausan, i. 35, 8. 
by Hamilton (who could not decipher the date), and afterwards by me in 1883 and again in 1887: 'A $\gamma a[\theta \grave{\eta}$ Tú $\chi \eta]$.

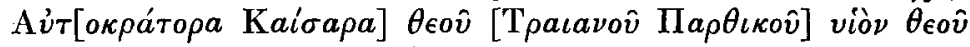

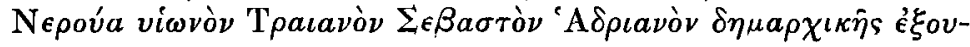

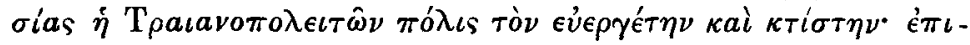

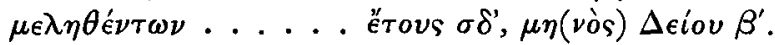

The date is end of September, A.D. 119, which proves that the inscription was not connected with a visit of Hadrian.

CIX.-Pulcherianopolis. The order of Hierocles shows that this city was situated on the Lydo-Phrygian frontier, south of Trajanopolis. I formerly thought that it might be a temporary name of Blaundos, but Blaundos is always placed in Lydia by the ecclesiastical documents, and there seems therefore no alternative except to identify Hierocles' Pulcherianopolis with the Metellopolis of the Notitiae. The situation of Metellopolis is certain. It was one of the first set of bishoprics attached to the metropolis of Hierapolis, and is therefore in the southwestern part of Pacatiana. It is identical with the Motella of numerous inscriptions, and the situation of Motella is given by these inscriptions and by the preservation of the name as Medele. ${ }^{1}$ The district of Motella is at present united with Dionysopolis and Hyrgalean Plain in a single district called Tchal. This modern unity existed in ancient time also, as is shown by the close religious connection which is seen in the inscriptions; and the name Pulcherianopolis reveals a stage in the gradual breaking up of these greater districts into smaller $\pi o ́ \lambda \epsilon \iota$ s. Dionysopolis was separated by the Pergamenian kings; Motella by Pulcheria in the fifth century.

CX.-The LYdo-Phrygian frontier is determined approximately by the preceding investigation. To fix it still more closely requires a discussion of the Lydian cities, which is at present too obscure a subject. The site of the Lydian Blaundos is well known since Hamilton; the Lydian Tralla was perhaps at the ancient site reported by Hamilton near Geune; Clannoudda is determined by the course of the Roman road from Pbiladelphia to Akmonia. This road must go either by Takmak or by Ine; on each of these routes, about 45 miles from Philadelphia

I In Part I. I failed to observe the identity of Motella and Metellopolis, and was obliged by the course of $\mathrm{my}$ investigation to put them side by side. I detected the identity just too late to change the text of my paper. 
there is an ancient site, one at Bei Sheher, ${ }^{1}$ the other at Ine. On the whole, considering that the latter road is much the easier, I incline to place Clannoudda at Ine, and to explain its apparent disappearance from history through its being at an early time absorbed in the territory of Blaundos. Bei Sheher then awaits a name. Bagis, Tabala, Maeonia, Saittae, and Silandos have all been determined by older travellers. To these I have to add Satala, a bishopric, which still retains its name as Sandal, near Koula. This situation is confirmed by the legend of Saint Therapon, who was led from Synaos towards Lydia through Satala, a city on the Maeander (Act. Sanct., May 27, p. 680).

The idea which has hitherto been generally accepted is that

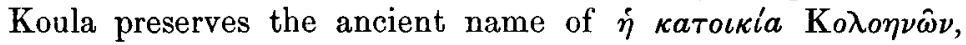
mentioned in an inscription ${ }^{2}$ now at Koula. I have seen this inscription, and have ascertained that it was brought to Koula from the district of Kara Tash, on the head-waters of the Hyllos, and that it was found there by workmen digging up madder-root. ${ }^{3}$ Koloe therefore was a village in the territory of the Temenothyreis. Moreover this town of Koula is mentioned by the Byzantine writers, who explain the name as a term used by the Turks in the sense 'castle;' it is the Arabic Kala.

I have now traversed the entire extent and bounds of Phrygia, except the southern frontier, which forms the subject of a special paper in the American Journal of Archaeology, 1887 and 1888, where I have corrected the site assigned in the first part of the present paper, according to the old idea, to Keretapa. ${ }^{4}$

W. M. RAMSAY.

I Called by Arundel Besh Sheher.

2 Wagener, Inscr. Grec. Recueillies en Asie Min. No. I. (read $\Delta$ for A, in day of month).

3 Koula was once a great centre for the madder-root trade, though in recent years madder-root has been superseded by bad cheap European dyes, and Kara Tash district, once rich, is now impoverished.

${ }^{4} \mathrm{~J}$ must correct the statement made by Mr. A. H. Smith in this Journal, p. 220, that 'the chief topographical results of our journey have been already published by Prof. Ramsay.' I purposely left the whole subject to Mr. Smith : but as his report was delayed, I published a very few topographical results, which were likely to have been discovered by more recent travellers. Those which I published made about a tenth part of the results of our journey : the rest may be found in the American Journal.

Note to LXXXVI. Aurokra is omitted Not. 